\title{
Mouse Panx1 Is Dispensable for Hearing Acquisition and Auditory Function
}

\author{
Veronica Zorzi ${ }^{1,2}$, Fabiola Paciello ${ }^{1}$, Gaia Ziraldo ${ }^{1,2}$, Chiara Peres ${ }^{1}$, Flavia Mazzarda ${ }^{1,3}$, \\ Chiara Nardin ${ }^{1,3}$, Miriam Pasquini ${ }^{1,4}$, Francesco Chiani ${ }^{1}$, Marcello Raspa ${ }^{1}$, \\ Ferdinando Scavizzi ${ }^{1}$, Andrea Carrer ${ }^{5}$, Giulia Crispino ${ }^{5}$, Catalin D. Ciubotaru ${ }^{6}$, \\ Hannah Monyer ${ }^{7}$, Anna R. Fetoni ${ }^{2}$, Anna M. Salvatore ${ }^{1}$ and Fabio Mammano ${ }^{1,5,8 *}$ \\ ${ }^{1}$ CNR Institute of Cell Biology and Neurobiology, Monterotondo, Italy, ${ }^{2}$ School of Medicine, Institute of Otolaryngology, \\ Catholic University, Rome, Italy, ${ }^{3}$ Department of Science, Roma Tre University, Rome, Italy, ${ }^{4}$ Department of Biology and \\ Biotechnology Charles Darwin, Sapienza University of Rome, Rome, Italy, ${ }^{5}$ Department of Physics and Astronomy G. Galilei, \\ University of Padua, Padua, Italy, ${ }^{6} \mathrm{CNR}$ Institute of Neuroscience, Padua Section, Padua, Italy, ${ }^{7}$ Department of Clinical \\ Neurobiology, Deutches Krebforschungzentrum, University of Heidelberg, Heidelberg, Germany, ${ }^{8}$ Shanghai Institute for \\ Advanced Immunochemical Studies, ShanghaiTech University, Shanghai, China
}

\section{OPEN ACCESS}

Edited by:

Isabel Varela-Nieto, Consejo Superior de Investigaciones Cientificas (CSIC), Spain

Reviewed by:

Maria E. Rubio, University of Pittsburgh, United States

Miguel A. Merchán, Universidad de Salamanca, Spain

${ }^{*}$ Correspondence: Fabio Mammano fabio.mammano@unipd.it

Received: 02 October 2017 Accepted: 30 October 2017 Published: 28 November 2017

Citation:

Zorzi V, Paciello F, Ziraldo G, Peres C, Mazzarda F, Nardin C, Pasquini M,

Chiani F, Raspa M, Scavizzi F, Carrer A, Crispino G, Ciubotaru CD,

Monyer H, Fetoni AR, Salvatore AM and Mammano F (2017) Mouse Panx1 Is Dispensable for Hearing Acquisition and Auditory Function.

Front. Mol. Neurosci. 10:379. doi: 10.3389/fnmol.2017.00379
Panx1 forms plasma membrane channels in brain and several other organs, including the inner ear. Biophysical properties, activation mechanisms and modulators of Panx1 channels have been characterized in detail, however the impact of Panx1 on auditory function is unclear due to conflicts in published results. To address this issue, hearing performance and cochlear function of the Panx $1-/-$ mouse strain, the first with a reported global ablation of Panx1, were scrutinized. Male and female homozygous (Panx1-/-), hemizygous (Panx1+/-) and their wild type (WT) siblings (Panx1+/+) were used for this study. Successful ablation of Panx1 was confirmed by RT-PCR and Western immunoblotting in the cochlea and brain of Panx1-/- mice. Furthermore, a previously validated Panx1-selective antibody revealed strong immunoreactivity in WT but not in Panx1-/- cochleae. Hearing sensitivity, outer hair cell-based "cochlear amplifier" and cochlear nerve function, analyzed by auditory brainstem response (ABR) and distortion product otoacoustic emission (DPOAE) recordings, were normal in Panx1+/- and Panx1-/- mice. In addition, we determined that global deletion of Panx1 impacts neither on connexin expression, nor on gap-junction coupling in the developing organ of Corti. Finally, spontaneous intercellular $\mathrm{Ca}^{2+}$ signal (ICS) activity in organotypic cochlear cultures, which is key to postnatal development of the organ of Corti and essential for hearing acquisition, was not affected by Panx 1 ablation. Therefore, our results provide strong evidence that, in mice, Panx1 is dispensable for hearing acquisition and auditory function.

Keywords: cochlea, pannexins, connexins, hair cells, non-sensory cells, auditory brainstem responses, distortion product otoacoustic emissions 


\section{INTRODUCTION}

Panx1 is the most thoroughly characterized member of the pannexin gene family (Panchin et al., 2000; Bruzzone et al., 2003; Baranova et al., 2004) encoding Panx1, Panx2 and Panx3 proteins ${ }^{1}$ that form plasma membrane channels known as pannexons (Sosinsky et al., 2011). Biophysical properties, activation mechanisms and modulators of Panx1 channels have been extensively reviewed (Dahl et al., 2013; Penuela et al., 2013; Dahl and Muller, 2014; Patel et al., 2014; Esseltine and Laird, 2016).

Quantification of Panx1 mRNA levels by quantitative real-time polymerase chain reaction (QPCR) in mouse central and peripheral nervous system, and various organs, revealed highest values in trigeminal ganglia $>$ bladder $>$ spleen, followed at distance by hippocampus $>$ cortex $\sim$ calvaria $>$ heart $>$ cerebellum, with lowest levels in kidney and spleen (Hanstein et al., 2013). Furthermore, Panx1 has been localized in eye (Ray et al., 2005; Kurtenbach et al., 2014), taste buds (Huang et al., 2007), olfactory system (Zhang et al., 2012) and inner ear (Tang et al., 2008; Wang et al., 2009; Zhao, 2016). As for the latter, the impact of Panx1 on auditory function is unclear due to recent publication of conflicting results.

The first Panx1 knockout mice (Panx $1^{\text {tm1Mony }}$, International strain designation B6;129-Panx $1^{\text {tm1.1Fama/Cnrm; }}$ EMMA ID:11476) $)^{2}$, hereafter referred to briefly as Panx1-/-, were reported in Anselmi et al. (2008). A subsequent study used in situ hybridization and western blot in brain extracts to confirm successful Panx1 deletion in these mice (Bargiotas et al., 2011). The same study determined that the following antibodies were not specific: goat anti-Panx1, sc-49695 (Santa Cruz); chicken anti-Panx1, no. ANT0027 (Diatheva); chicken anti-human Panx1, \#4515, provided by G. Dahl (University of Miami School of Medicine); rabbit anti-Panx1, provided by G. Zoidl (Bochum, Germany). Panx1-/- mice displayed altered electroretinograms in response to light flashes (Kranz et al., 2013), whereas no auditory phenotype was detected by auditory brainstem response (ABR) analysis (Anselmi et al., 2008 ${ }^{3}$ ).

Other researchers used mice with loxP sites flanking exon 2 of Panx1, obtained from Genentech. Deletion of exon 2 (which introduces a frameshit and premature stop codon), was accomplished by breeding to C57BL/6-

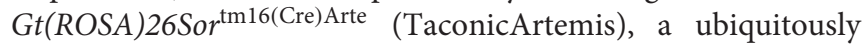
active Cre deleter line (Otto et al., 2009). Offspring were backcrossed several times to C57BL/ 6 mice, to breed out the Cre recombinase, resulting in a knockout strain henceforth referred to as Genentech-Panx1-/-. Successful ablation of Panx1 was confirmed in several organs on these mice (muscle, lung, liver, kidney, tail, brain, heart, thymus, spleen and skin tissues; Qu et al., 2011; Cone et al., 2013; Penuela et al., 2014) as well as in the cochlea (Abitbol et al., 2016). Genentech-Panx1-/- mice exhibited neither reduced hearing sensitivity nor cochlear nerve defects; furthermore, susceptibility to noise-induced hearing loss

\footnotetext{
${ }^{1}$ http://www.genenames.org/cgi-bin/genefamilies/set/288

${ }^{2} \mathrm{http}$ ///www.informatics.jax.org/allele/MGI:5310802

${ }^{3}$ http://www.informatics.jax.org/marker/phenotypes/MGI:1860055
}

in these mice was indistinguishable from that of their wild type (WT) controls (Abitbol et al., 2016).

A strain carrying the Pan $x 1^{\text {tmla(KOMP)Wtsi }}$ allele was generated by the Knock Out Mouse Project $\left(\mathrm{KOMP}^{4}\right)$ using the multipurpose tmla knockout-first promoter-driven selection cassette, which has been adopted also by other major mouse knockout programs such as EUCOMM (EUropean Conditional Mouse Mutagenesis Program ${ }^{5}$; International Mouse Knockout et al., 2007). The versatile tmla allele contains an IRES:lacZ trapping cassette and a floxed promoter-driven neo cassette inserted into the intron of a gene, disrupting gene function ${ }^{6}$. However, mice homozygous for the Panx $1^{\text {tmla(KOMP)Wtsi }}$ knockout-first promoter-driven allele were found to express about $30 \%$ residual Panx1 mRNA in all organs examined, leading to the conclusion that $\operatorname{Pan} x 1^{\mathrm{tmla} \text { (KOMP)Wtsi }}$ is a hypomorphic allele (Hanstein et al., 2013). Hypomorphism has been reported also for other knockout-first alleles (Shpargel et al., 2012; Ryder et al., 2014).

Aiming to achieve Panx1 conditional deletion in the cochlea, Chen et al. (2015) crossed the hypomorphic Pan $x 1^{\text {tmla(KOMP)Wtsi }}$ mice with Foxg1-Cre mice (Hébert and McConnell, 2000; Bredenkamp et al., 2007), and identified homozygous Foxg1 ${ }^{\mathrm{Cre}}: \mathrm{Panx}^{\mathrm{f} / \mathrm{f}}$ mice as conditional Panx1 knockout mice (henceforth referred to as Foxg1-cPanx1-/-). Intense immunofluorescence labeling with the non-specific chicken anti-human Panx1 antibody \#4515 was detected in the spiral limbus and organ of Corti, but not in the lateral wall of Foxg1cPanx1-/- mice, which had significantly elevated hearing thresholds at all frequencies, reduced endocochlear potential and reduced cochlear microphonics (Chen et al., 2015).

Zhao et al. (2015) crossed Panx $1^{\text {tmla(KOMP)Wtsi }}$ mice with Paired box 2 Cre (Pax2-Cre) mice (Tian et al., 2006; Ohyama, 2009) to generate yet another strain of Panxl conditional knockout in the cochlea (henceforth referred to as Pax2cPanx1-/-). ABR thresholds of Pax2-cPanx1-/- mice were $40 \mathrm{~dB}$ sound pressure level (SPL) greater than in WT littermates at P80 (where P0 is day of birth). Likewise, DPOAEs were significantly decreased in Pax2-cPanx1-/- mice compared to WT (Zhao et al., 2015) at P50.

In the light of these contrasting results, the goal of the present study was to clarify the role of Panx1 in hearing. To this end, we re-evaluated hearing performance and cochlear function of Panx1-/- mice using in vivo electrophysiology, plus a variety of biochemical and biophysical assays.

\section{MATERIALS AND METHODS}

\section{Ethics Statement}

Animal work was performed in accordance with a protocol approved by the Italian Ministry of Health (Authorization n.1005/2016-PR, date 21/10/2016, DGSAF Prot. No. 002451-P25/10/2016 and No. 0001276-P-19/01/2016).

\footnotetext{
${ }^{4} \mathrm{http}: / /$ www.knockoutmouse.org

${ }^{5} \mathrm{http}: / /$ www.eucomm.org

${ }^{6} \mathrm{http}: / /$ www.komp.org/alleles.php\#conditional-promoter-csd
} 


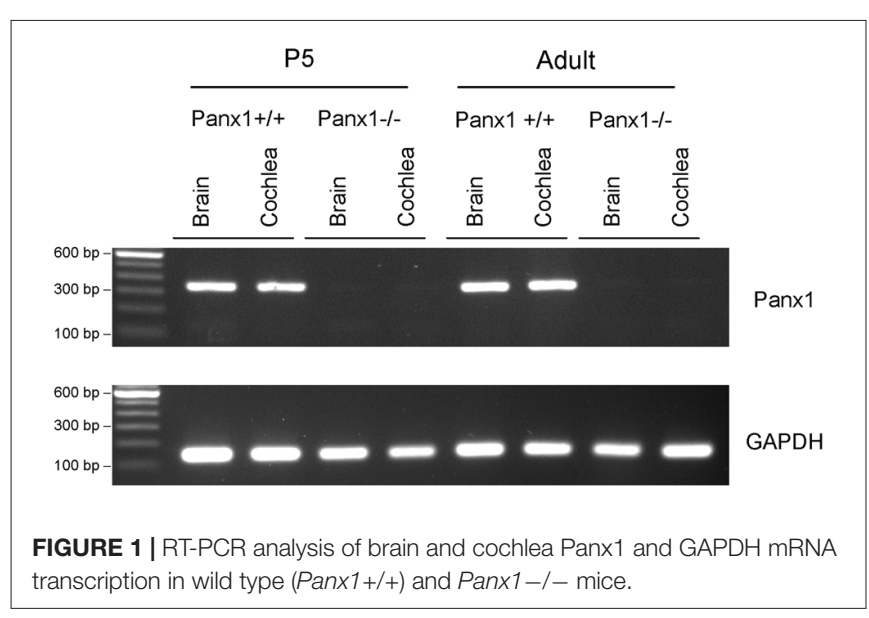

\section{Animals and Genotyping}

Animals were bread and genotyped in the CNR Monterotondo node of the European Mouse Mutant Archive (EMMA; del Hierro et al., 2016), an ESFRI/INFRAFRONTIER Distributed Research Infrastructure ${ }^{7}$.

Mice tested were P5 pups and adults (1-3 months of age). Male and female homozygous (Panx1-l-), hemizygous $($ Pan $x 1+/-)$ and their WT siblings $($ Pan $x 1+/+)$ were used for this study. The background strains of these mice was C57BL/6N.

Pan $x 1$ mice were genotyped according to published protocols by standard PCR on extracted mouse tail tips (Anselmi et al., 2008; Bargiotas et al., 2011) using the following primers:

\section{- Panx1 f: 5'-GGAAAGTCAACAGAGGTACCC-3' \\ - Panx1 r: 5'-CTTGGCCACGGAGTATGTGTT-3' \\ - LacZ: 5'-GTCCCTCTCACCACTTTTCTTACC-3'}

The Pan $x 1+/+$ allele was targeted by the above $\mathrm{f}$ and $\mathrm{r}$ primers and identified by a 330 bp band, whereas Panx1-/- was targeted by primers Panx $1 \mathrm{f}$ and LacZ, and was identified by a $630 \mathrm{bp}$ band. Panx1+/- was identified by the simultaneous presence of a $330 \mathrm{bp}$ and a $630 \mathrm{bp}$ band.

For some internal control experiments, mice with ubiquitous deletion of connexin 30 (Cx30-/-; International strain name B6.129P2-Gjb6 $6^{\mathrm{tm} 1 \mathrm{Kwi} / \mathrm{Cnrm}}$; EMMA ID: 00323; MGI ID: 2447863; Teubner et al., 2003; Cohen-Salmon et al., 2007; Schütz et al., 2010; Johnson et al., 2017) were also used. The background strains of these mice was C57BL/6J. Cx30-/mice were genotyped as indicated in the protocol provided by INFRAFRONTIER:

- Cx30 f: 5'-GGTACCTTCTACTAATTAGCTTGG-3'

- Cx30 r: 5'-AGGTGGTACCCATTGTAGAGGAAG-3'

- LacZ: 5'-AGCGAGTAACAACCCGTCGGATTC-3'

Cx30+/+ mice were identified by a 544 bp band, whereas Cx30-I- mice were identified by a 460 bp band.

\footnotetext{
${ }^{7}$ https://www.infrafrontier.eu/
}

\section{RNA Extraction and RT-PCR}

Following euthanasia, cochleae and brains were dissected from adult and P5 Panx $1+/+$ and Panx1-/- mice and flash-frozen in liquid nitrogen. Total RNA was extracted with RNeasy mini kit (Qiagen, Cat. No. 74106) and retrotranscribed with oligo-dT 12-18 primers (ThermoFisher, Cat. No. 18418012) using Omniscript RT kit (Qiagen, Cat. No. 205111). Subsequently RT-PCR was performed using PCR BIO HS Taq Mix Red (PB10.23-02). The PCR profile was: $95^{\circ} \mathrm{C}$ for $5 \mathrm{~min}, 94^{\circ} \mathrm{C}$ for $15 \mathrm{~s}, 62^{\circ} \mathrm{C}$ for $30 \mathrm{~s}, 72^{\circ} \mathrm{C}$ for $15 \mathrm{~s}$ and $72^{\circ} \mathrm{C}$ for $2 \mathrm{~min}$ for 34 cycles. Primers used were:

- Panx1 ex3 f: 5'-ACACCTCTGCTCAGACCTGAA-3'

- Panx1 ex4 r: $5^{\prime}$-TGCACAGAAACTCGCGTCCGAGA-3'

- GAPDH f: 5'-ATGTGTCCGTCGTGGATCTGAC-3'

- GAPDH r: 5'-AGACAACCTGGTCCTCAGTGTAG-3'

The amplified products were run on a 1,5\% agarose gel with SYBR Safe (ThermoFisher, Cat. No. S33102) for visualization of the Panx1 band (336 bp) and the GAPDH band (132 bp) (Figure 1).

\section{QPCR}

QPCR was performed on cDNA to amplify $C x 26$ and $C x 30$ and was normalized to GAPDH. Gene expression relative to GAPDH was estimated according to a published method (Pfaffl, 2001). Amplification was carried out using Power SYBR Green (Applied Biosystems, Cat. No. 4367659) on the ABI 7700 sequence detection system equipped with ABI Prism 7700 SDS software (Applied Biosystems) through the following amplification cycles: $50^{\circ} \mathrm{C}$ for $2 \mathrm{~min}, 95^{\circ} \mathrm{C}$ for $10 \mathrm{~min}, 95^{\circ} \mathrm{C}$ for $15 \mathrm{~min}, 60^{\circ} \mathrm{C}$ for $1 \mathrm{~min}$ (40 cycles). Primers used are as follows:

- Cx26 f: 5' -TCACAGAGCTGTGCTATTTG-3'

- Cx26 r: 5'-ACTGGTCTTTTGGACTTTCC-3'

- Cx30 f: 5'-GGCCGAGTTGTGTTACCTGCT-3'

- Cx30 r: 5'-TCTCTTTCAGGGCATGGTTGG-3'

- GAPDH f: $5^{\prime}$-ATGTGTCCGTCGTGGATCTGAC-3'

- GAPDH r: 5'-AGACAACCTGGTCCTCAGTGTAG-3'

\section{Western Immunoblotting}

Total proteins were extracted from brains and cochleae of P5 and adult Panx1+/+ $(n=4)$ and Panx1-/- mice $(n=4)$. Tissues were dissected, collected on liquid nitrogen, stored at $-80^{\circ} \mathrm{C}$ and homogenized by using ice cold RIPA buffer (Pierce; $50 \mathrm{mM}$ Tris, $150 \mathrm{mM} \mathrm{NaCl}, 1 \mathrm{mM}$ EDTA, $1 \%$ DOC, $1 \%$ Triton X-100, $0.1 \%$ SDS, and $1 \times$ protease, phosphatase- 1 , and phosphatase-2 inhibitor cocktails [Sigma]). The lysate was sonicated three times at $10 \mathrm{~Hz}$ (Hielscher, Ultrasound Technology UP50H/UP100H), centrifuged (13,000 rpm, $15 \mathrm{~min}, 4^{\circ} \mathrm{C}$ ), and a $5 \mu \mathrm{l}$ aliquot of the supernatant was assayed to determine the protein concentration (microBCA kit, Pierce). SDS-PAGE reducing sample buffer was added to the supernatant, and samples were heated to $95^{\circ} \mathrm{C}$ for $5 \mathrm{~min}$. Protein lysates $(70 \mu \mathrm{g})$ were loaded onto $12 \%$ Tris-glycine polyacrylamide gels for electrophoretic separation. ColorburstTM Electrophoresis markers (Sigma) were used 


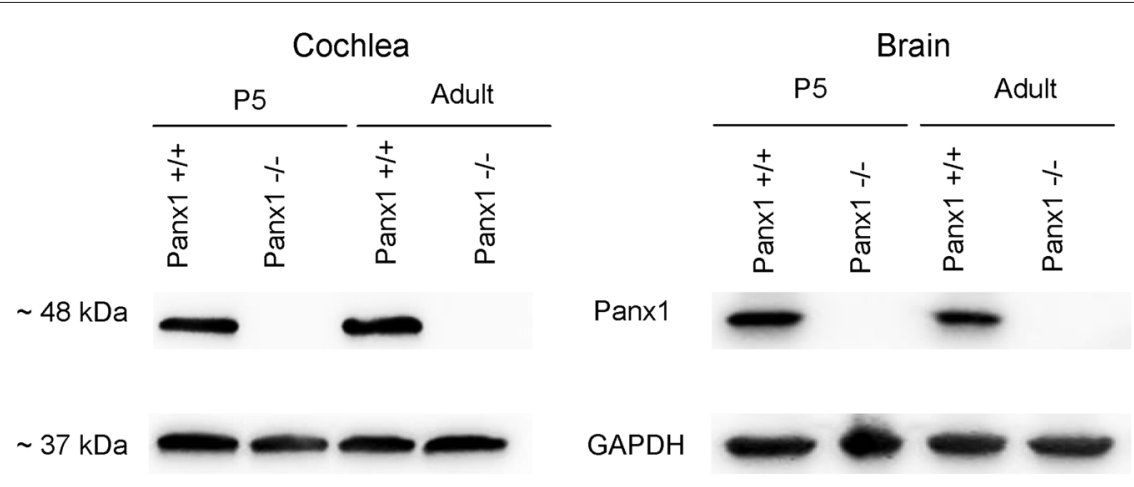

FIGURE 2 | Western blot with a Panx1-selective antibody in cochlea and brain.
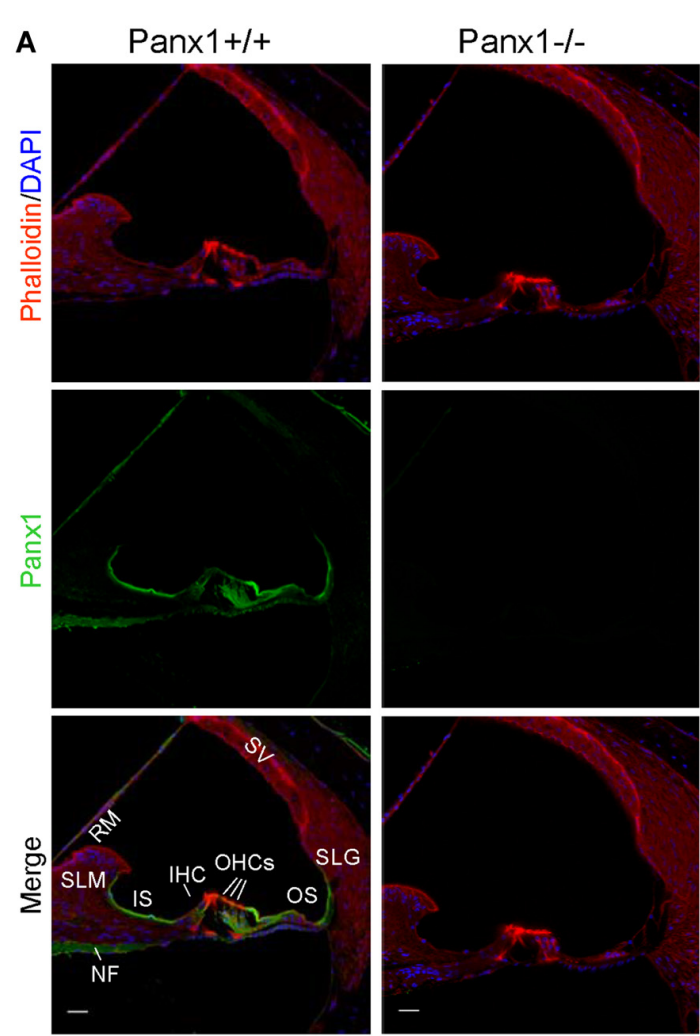
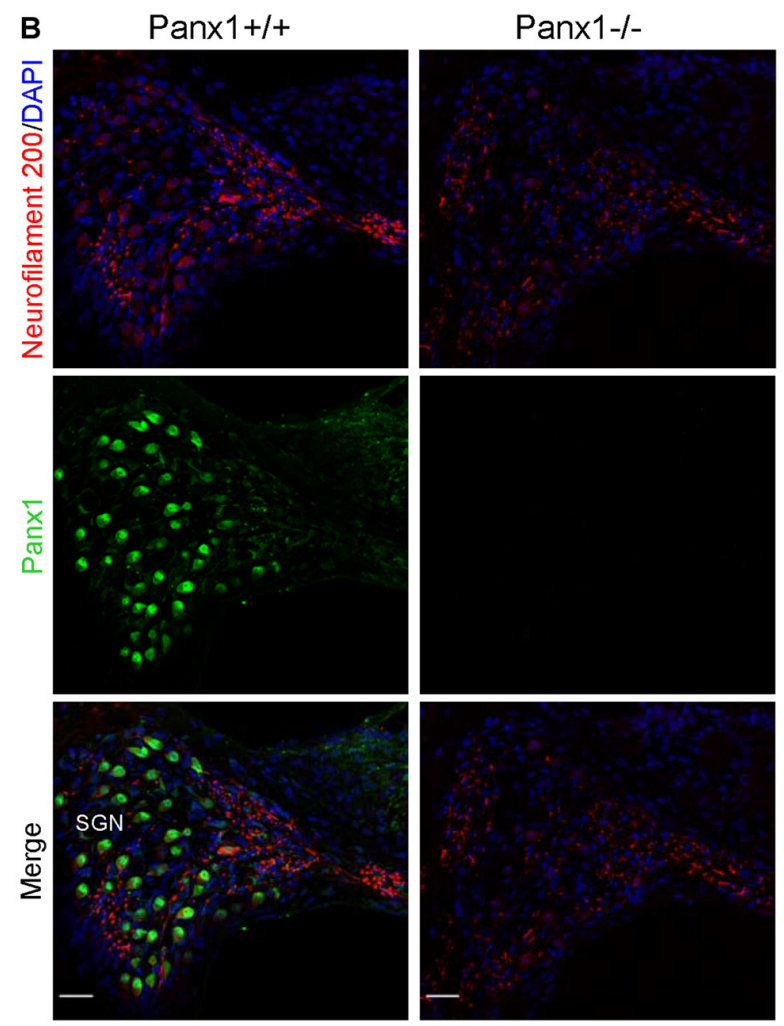

FIGURE 3 | Immunofluorescence with a validated Panx1-selective antibody in cochlear midmodiolar sections. (A) Representative transversal sections of scala media. Shown are maximal projection rendering of three consecutive confocal optical sections taken at $0.5 \mu \mathrm{m}$ intervals in the apical cochlear turn; actin filaments were stained with phalloidin (red) and nuclei with DAPI (blue); Panx1 expression was detected with the AvesLab \#6358 selective antibody (green). IHC, inner hair cells; OHCs, outer hair cells; RM, Reissner's membrane; SV, stria vascularis; SLM, spiral limbus; SLG, spiral ligament; IS, inner sulcus; OS, outer sulcus; NF, nerve fibers. Gamma filters were applied to both red $(\gamma=0.40)$ and green $(\gamma=0.55)$ channels. Scale bars: $25 \mu \mathrm{m}$. (B) Representative transversal sections of spiral ganglion. Maximal projection rendering of 10 consecutive confocal optical sections taken at $1.5 \mu \mathrm{m}$ intervals in the medial cochlear turn; nerve fibers were stained with a neurofilament 200 selective antibody (red). SGN, spiral ganglion neurons. Gamma filters were applied to both red $(\gamma=0.55)$ and green $(\gamma=0.9)$ channels. Scale bars: $25 \mu \mathrm{m}$.

as molecular mass standards. Proteins were then transferred onto nitrocellulose membranes at $100 \mathrm{~V}$ for $2 \mathrm{~h}$ at $4^{\circ} \mathrm{C}$ in transfer buffer containing $25 \mathrm{mM}$ Tris, $192 \mathrm{mM}$ glycine, $0.1 \%$ SDS and $20 \%$ methanol. Membranes were incubated for
$1 \mathrm{~h}$ with blocking buffer (5\% skim milk in TBST), and then incubated overnight at $4^{\circ} \mathrm{C}$ with primary antibodies directed against Panxl (1 mg/ml, ThermoFisher, Cat. No. 487900), Cx26 (1 mg/ml, ThermoFisher, Cat. No. 512800), Cx30 

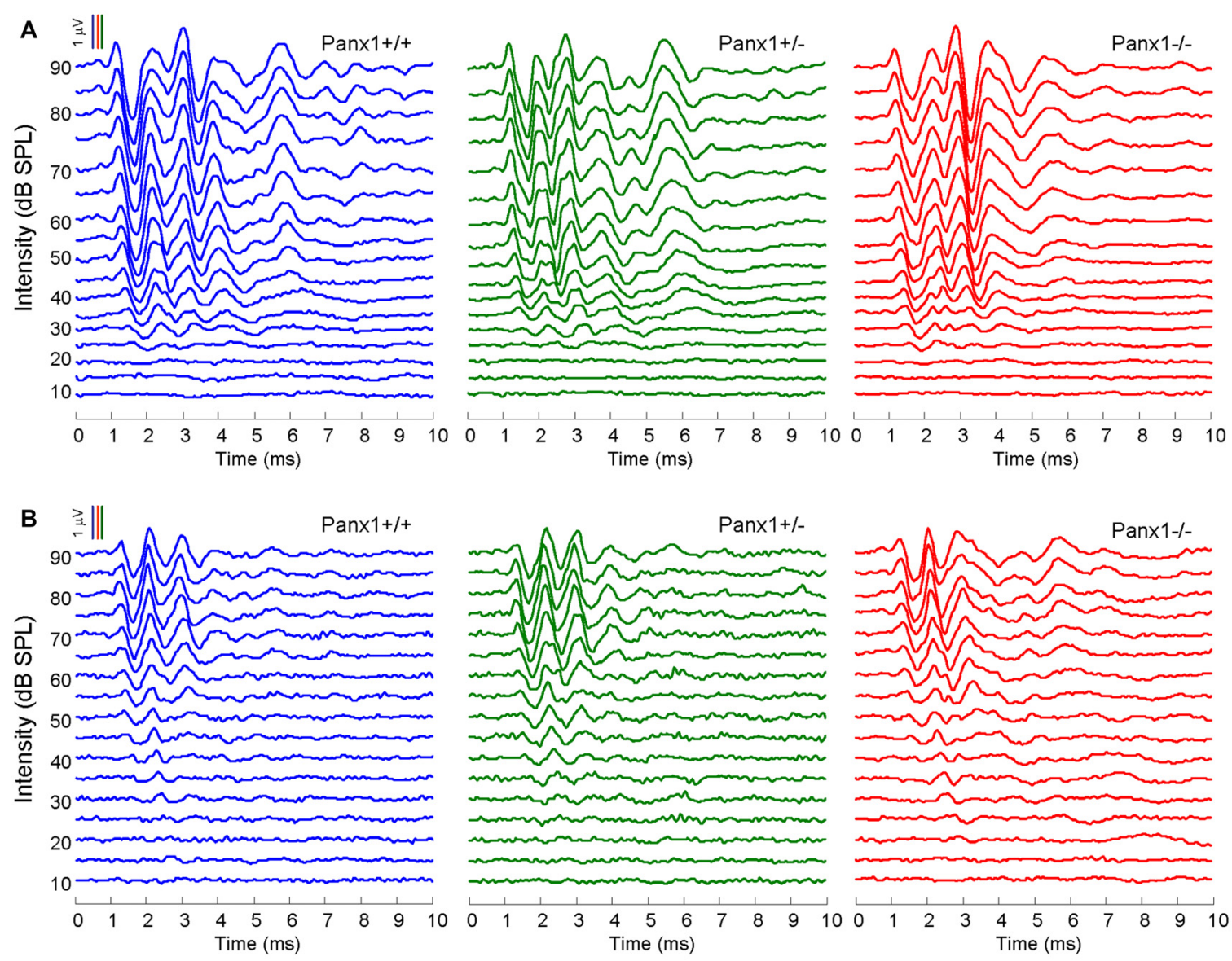

FIGURE 4 | In vivo electrophysiological recordings. (A,B) Representative recordings of auditory brainstem responses (ABRs) evoked by clicks (A) and $24 \mathrm{kHz}$ tone burst stimuli (B).

(1 $\mathrm{mg} / \mathrm{ml}$, ThermoFisher, Cat. No. 712200) and GAPDH (1:2500, Abcam). After three $10 \mathrm{~min}$ rinses in TBST, membranes were incubated for $1 \mathrm{~h}$ at room temperature $\left(22-25^{\circ} \mathrm{C}\right)$ with HRP-conjugated secondary antibodies (Cell Signaling, 1:2500). The membranes were then washed, and the bands were visualized with an enhanced chemiluminescence detection kit (GE Healthcare, UK). Protein expression was evaluated and documented by using a UVItec Cambridge Alliance system.

\section{Immunohistochemistry and Confocal Imaging}

Cochleae were extracted from P5 and adult mice and processed as previously described (Crispino et al., 2011, 2017). Briefly, samples were fixed in $4 \%$ paraformaldehyde and decalcified in ethylenediaminetetraacetic acid (EDTA, $0.3 \mathrm{M}$ ). Specimens were included in 3\% agarose dissolved in PBS and cut in 100 $\mu \mathrm{m}$ thickness steps using a vibratome (VT $1000 \mathrm{~S}$, Leica). Tissue slices were permeabilized with $0.1 \%$ Triton X-100, dissolved in bovine serum albumin $2 \%$ solution. Panx1 was immunolabeled by overnight incubation at $4^{\circ} \mathrm{C}$ with a chicken
anti-Panx1 specific antibody (1:500; extracellular loop epitope: VQQKSSLQSES, AvesLab \#6358; Hanstein et al., 2013) provided by Prof. Eliana Scemes. Cx30 and Cx26 were immunolabeled by overnight incubation at $4{ }^{\circ} \mathrm{C}$ respectively with a rabbit polyclonal $\mathrm{Cx} 30$ and a mouse monoclonal Cx26 selective antibody $(10 \mu \mathrm{g} / \mathrm{ml}$, ThermoFisher, Cat. No. 712200 for Cx30; Cat. No. 335800 for Cx26). Secondary antibodies (10 $\mu \mathrm{g} / \mathrm{ml})$ were: Alexa Fluor ${ }^{\circledR} 488$ goat anti-chicken $\operatorname{IgY}(\mathrm{H}+\mathrm{L})$, ThermoFisher, Cat. No. A11039; Alexa Fluor ${ }^{\circledR} 488$ goat anti-rabbit IgG, ThermoFisher, Cat. No. A11008; Alexa Fluor ${ }^{\circledR}$ 488 goat anti-mouse IgG, ThermoFisher, Cat. No. A11029), applied at room temperature $\left(22-25^{\circ} \mathrm{C}\right)$. F-Actin was stained by incubation with AlexaFluor 568 phalloidin $(1 \mathrm{U} / \mathrm{ml}$, ThermoFisher, Cat. No. A12380), and nuclei were stained with $4^{\prime}, 6^{\prime}$ diamidino-2' phenylindole (DAPI, ThermoFisher, Cat. No. D1306; 1:200). The same immunostaining procedure was used also for organotypic cultures from P5 pups. All samples were mounted onto glass slides with a mounting medium (FluorSaveTM Reagent, Merk, Cat. No. 345789) and analyzed using a confocal microscope (TCS SP5, Leica) equipped with an oil-immersion objective (40× HCX PL APO 1.25 N.A., Leica). 

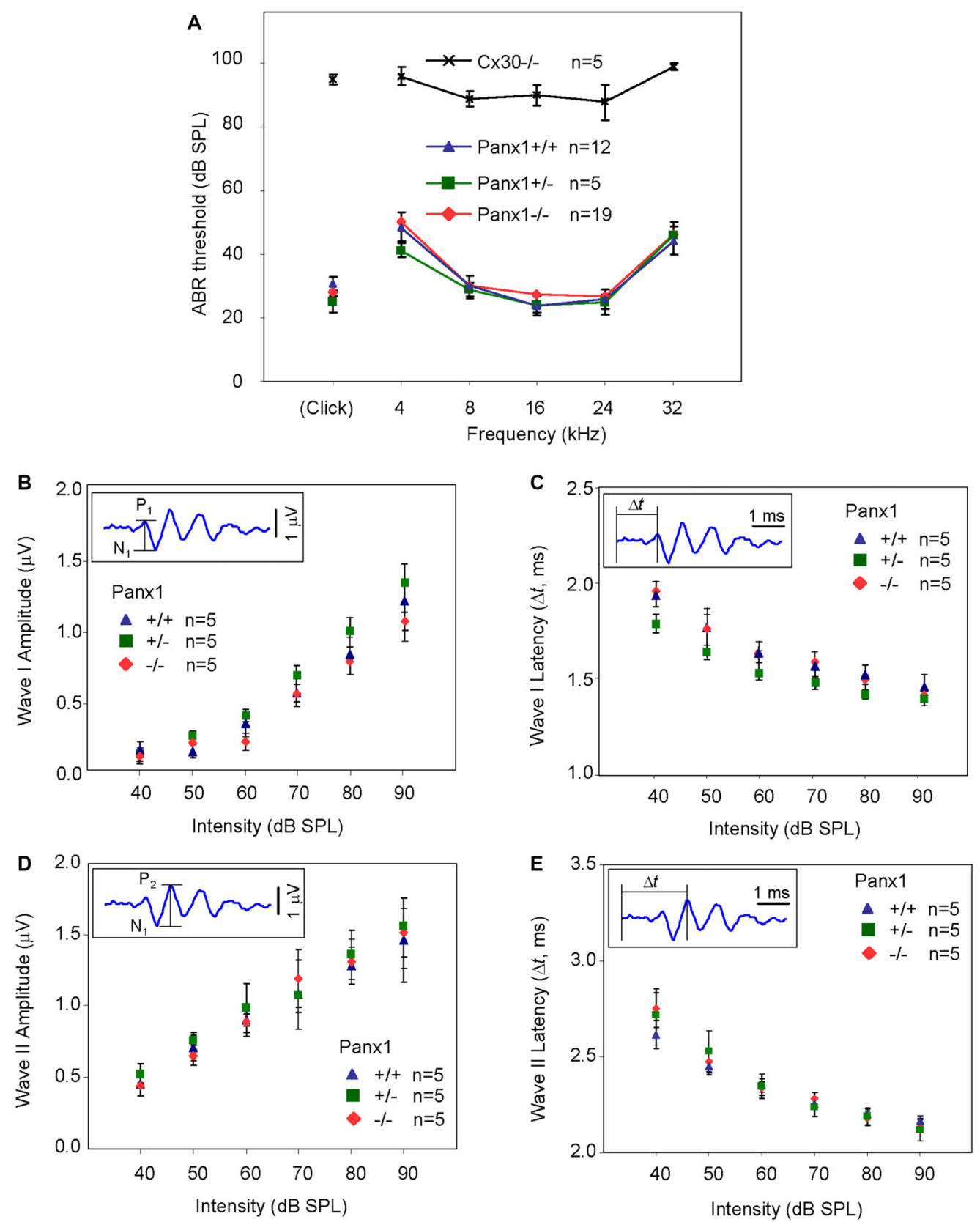

FIGURE 5 | ABR analysis. (A) Hearing threshold estimated from Wave II for clicks and tone bursts at 4, 8, 16, 24, 32 kHz; Cx30-/- mice were used as an internal control. (B) Amplitude of Wave I (see inset) evoked by $24 \mathrm{kHz}$ tone vs. stimulus intensity. (C) Latency of Wave I (see inset) evoked by $24 \mathrm{kHz}$ tone pips vs. stimulus intensity. (D) Amplitude of Wave II (see inset) evoked by $24 \mathrm{kHz}$ tone vs. stimulus intensity. (E) Latency of Wave II (see inset) evoked by 24 kHz tone pips vs. stimulus intensity. Error bars represent SEM. See also Tables 1-5.

\section{ABR and DPOAE Measurement}

Auditory function was assessed in a sound-attenuating enclosure (ETS-Lindgren SD Test Enclosure, MDL Technologies Limited, Hitchin, UK) using an ABR Workstation (Tucker-Davis Technologies, Inc., Alachua, FL, USA) comprising: Z-Series 3-DSP Bioacoustic System w/Attenuators and Optic fiber; Medusa 4-Channel Pre-Amp/Digitizer; Medusa 4-Channel
Low Imped. Headstage; MF1-M Multi Field Magnetic Speakers-Mono; AEP/OAE Software for RZ6; Experiment Control Workstation. Sound levels were calibrated using a $\frac{1}{4}$ inch Free Field Measure Calibration Microphone Kit (Model 480C02; PCB).

Mice were anesthetized with intraperitoneal injections of ketamine (70 mg/g for males, $100 \mathrm{mg} / \mathrm{g}$ for females) 
TABLE 1 | Auditory brainstem response (ABR) thresholds for click stimuli and for tone bursts at 4, 8, 16, 24, 32 kHz obtained from Pan $1+/+$, Pan $x 1+/-$ and Pan $x 1$-/mice.

\begin{tabular}{|c|c|c|c|}
\hline & Panx1+/+ $n=12$ & Panx1+l- $n=5$ & Panx1-I- $n=19$ \\
\hline Click & $31(5)$ & $27(4)[p=0.096]$ & $28(4)[p=0.096]$ \\
\hline $4 \mathrm{kHz}$ & $48(12)$ & $41(7)[p=0.125]$ & $52(12)[p=0.47]$ \\
\hline $8 \mathrm{kHz}$ & $30(8)$ & $29(4)[p=0.73]$ & $31(8)[p=0.85]$ \\
\hline $16 \mathrm{kHz}$ & $24(7)$ & $24(5)[p=0.94]$ & $27(8)[p=0.21]$ \\
\hline $24 \mathrm{kHz}$ & $26(8)$ & $25(5)[p=0.79]$ & $26(8)[p=0.79]$ \\
\hline $32 \mathrm{kHz}$ & $44(11)$ & $46(8)[p=0.71]$ & $47(14)[p=0.59]$ \\
\hline
\end{tabular}

Shown are mean values in $\mathrm{dB} S \mathrm{SP}$, rounded to nearest integer, with standard deviation (in round brackets), and paired t-test $p$-values of each group relative to Panx $1+/+$ (i.e., WT) controls (in square brackets).

TABLE 2 | Wave I amplitude-intensity functions across animals in response to $24 \mathrm{kHz}$ tone bursts.

\begin{tabular}{|c|c|c|c|}
\hline dB SPL & Panx1+/+n = 5 & Panx1+/-n = 5 & Panx1-I- $n=5$ \\
\hline 90 & $1.23(0.44)$ & $1.08(0.656)[p=0.44]$ & $1.37(0.37)[p=0.39]$ \\
\hline 80 & $0.85(0.28)$ & $0.82(0.361)[p=0.91]$ & $1.02(0.33)[p=0.40]$ \\
\hline 70 & $1.58(0.314)$ & $0.58(0.32)[p=0.99]$ & $0.72(0.16)[p=0.21]$ \\
\hline 60 & $0.38(0.187)$ & $0.24(0.11)[p=0.56]$ & $0.44(0.08)[p=0.47]$ \\
\hline 50 & $0.17(0.09)$ & $0.25(0.13)[p=0.52]$ & $0.29(0.04)[p=0.07]$ \\
\hline 40 & $0.413(0.06)$ & $0.11(0.04)[p=0,68]$ & $0.16(0.04)[p=0.41]$ \\
\hline
\end{tabular}

Shown are mean values in $\mu \mathrm{V}$, with standard deviation (in round brackets), and paired t-test p-values of each group relative to Panx $1+/+$ (i.e., WT) controls (in square brackets).

TABLE 3 | Wave I latency-intensity functions across animals in response to $24 \mathrm{kHz}$ tone bursts.

\begin{tabular}{|c|c|c|c|}
\hline dB SPL & $\operatorname{Pan} x 1+/+n=8$ & $\operatorname{Panx1+/-n}=5$ & Panx1-I- $n=6$ \\
\hline 90 & $1.42(0.17)$ & $1.38(0.07)[p=0.64]$ & $1.36(0.07)[p=0.52]$ \\
\hline 80 & $1.48(0.15)$ & $1.47(0.05)[p=0.89]$ & $1.39(0.05)[p=0.24]$ \\
\hline 70 & $1.54(0.16)$ & $1.56(0.08)[p=0.77]$ & $1.44(0.07)[p=0.627]$ \\
\hline 60 & $1.61(0.16)$ & $1.60(0.06)[p=0.92]$ & $1.50(0.05)[p=0.19]$ \\
\hline 50 & $1.74(0.25)$ & $1.74(0.18)[p=0.98]$ & $1.61(0.04)[p=0.28]$ \\
\hline 40 & $1.92(0.25)$ & $1.94(0.28)[p=0.92]$ & $1.76(0.10)[p=0.21]$ \\
\hline
\end{tabular}

Shown are mean values in ms, with standard deviation (in round brackets), and paired t-test p-values of each group relative to Panx1+/+ (i.e., WT) controls (in square brackets).

\begin{tabular}{|c|c|c|c|}
\hline dB SPL & $\operatorname{Panx1}+/+n=5$ & Panx1-I- $n=5$ & Panx1-I- $n=5$ \\
\hline 90 & $1.43(0.40)$ & $1.53(0.65)[p=0.786]$ & $1.49(0.38)[p=0.837]$ \\
\hline 80 & $1.26(0.19)$ & $1.33(0.39)[p=0.703]$ & $1.28(0.36)[p=0.880]$ \\
\hline 70 & $1.05(0.35)$ & $1.05(0.28)[p=0.984]$ & $1.16(0.46)[p=0.675]$ \\
\hline 60 & $0.87(0.18)$ & $0.96(0.38)[p=0.668]$ & $0.86(0.22)[p=0.903]$ \\
\hline 50 & $0.68(0.16)$ & $0.73(0.13)[p=0.590]$ & $0.62(0.16)[p=0.624]$ \\
\hline 40 & $0.42(0.13)$ & $0.49(0.17)[p=0.496]$ & $0.41(0.17)[p=0.935]$ \\
\hline
\end{tabular}

Shown are mean values in $\mu \mathrm{V}$, with standard deviation (in round brackets), and paired t-test p-values of each group relative to Panx1+/+ (i.e., WT) controls (in square brackets).

TABLE 5 | Waves II latency-intensity functions across animals in response to $24 \mathrm{kHz}$ tone bursts.

\begin{tabular}{|c|c|c|c|}
\hline dB SPL & $\operatorname{Panx1+/+n}=8$ & Panx1-I- $n=5$ & Panx1-I- $n=6$ \\
\hline 90 & $2.16(0.08)$ & $2.12(0.13)[p=0.55]$ & $2.14(0.06)[p=0.60]$ \\
\hline 80 & $2.2(0.07)$ & $2.19(0.10)[p=0.84]$ & $2.18(0.09)[p=0.66]$ \\
\hline 70 & $2.23(0.09)$ & $2.24(0.11)[p=0.86]$ & $2.28(0.08)[p=0.67]$ \\
\hline 60 & $2.35(0.10)$ & $2.34(0.14)[p=0.89]$ & $2.33(0.09)[p=0.70]$ \\
\hline 50 & $2.14(0.9)$ & $2.53(0.24)[p=0.27]$ & $2.47(0.17)[p=0.33]$ \\
\hline 40 & $2.62(0.21)$ & $2.71(0.26)[p=0.53]$ & $2.75(0.25)[p=0.32]$ \\
\hline
\end{tabular}

Shown are mean values in ms, with standard deviation (in round brackets), and paired t-test p-values of each group relative to Panx1+/+ (i.e., WT) controls (in square brackets).

and medetomidine $(1 \mathrm{mg} / \mathrm{g})$. The depth of anesthesia was periodically verified by the lack of foot-pinch response.
Body temperature was maintained at $37^{\circ} \mathrm{C}$ using a heating pad under feedback control. Corneal drying was prevented 
by application of ophthalmic gel to the eyes of the animals.

For ABR recordings (Scimemi et al., 2014), acoustic stimuli consisted of clicks (100 $\mu \mathrm{s}$ duration) and tone bursts (1 ms rise-fall time with $3 \mathrm{~ms}$ plateau) of $4,8,16,24$ and $32 \mathrm{kHz}$, and were delivered in the free field using a MF1-M speaker. Bioelectrical potentials were collected with gauge 27, $13 \mathrm{~mm}$ needle electrodes (Cat. No. S83018-R9, Rochester) inserted subdermally at the vertex (active), ventrolateral to the left ear (reference) and above the tail (ground). Potentials were amplified, filtered $(0.3-3 \mathrm{kHz})$ and averaged over 512 presentations of the same stimulus. Hearing threshold levels were determined offline as the SPL at which a Wave II peak, could be visually identified above the noise floor $(0.1 \mu \mathrm{V})$.

Otoacoustic emissions (Kemp, 1978) were evoked using a pair of equal intensity primary tones, $f_{1}=14,544 \mathrm{~Hz}$, and $f_{2}=17,440 \mathrm{kHz}$ delivered at intensities ranging from 20 to $80 \mathrm{~dB}$ SPL in $10 \mathrm{~dB}$ SPL increments. Each primary tone $(20.97 \mathrm{~ms}$ duration, 47/s) was emitted by a separate MF1-M speaker, configured for closed field stimulation, and delivered to the mouse ear via a small tube as prescribed by the manufacturer. The cubic distortion product $2 f_{1}-f_{2}=11,648 \mathrm{kHz}$, was detected using a small microphone (ER10B+ Low Noise Probe and Microphone, Etymotic Research, IL, USA) coupled to the ear canal.

\section{Preparation of Cochlea Organotypic Cultures}

Cochleae from P5 mouse pups were quickly dissected in ice-cold Hepes buffered (pH 7.2) HBSS (ThermoFisher, Cat. No. 14025050), placed onto $12 \mathrm{~mm}$ glass coverslips coated with Cell-Tak (Biocoat, Cat. No. 354240) and incubated overnight at $37^{\circ} \mathrm{C}$ in DMEM/F12 (ThermoFisher, Cat. No. 11320-074) supplemented with 5\% FBS (ThermoFisher, Cat. No. 10270-106) and $100 \mu \mathrm{g} / \mathrm{ml}$ ampicillin (Sigma-Aldrich, Cat. No. A0166).

\section{Dye Transfer Assays in Cochlear Organotypic Cultures}

To visualize gap junction coupling among non-sensory cells of the lesser epithelial ridge (LER), we performed dye-transfer assays using the fluorescent tracer Lucifer Yellow (LY, CH Lithium Salt, Thermofisher, \#L12926) for microinjection. Cochlear cultures were transferred on the stage of a spinning disk confocal microscope (DSU, Olympus) and perfused for $5 \mathrm{~min}$ at $1 \mathrm{ml} / \mathrm{min}$ with EXM, an extracellular solution containing (in mM): $\mathrm{NaCl} 135, \mathrm{KCl} 5.8, \mathrm{CaCl} 21.3, \mathrm{NaH}_{2} \mathrm{PO}_{4}$ 0.7, $\mathrm{MgCl}_{2}$ 0.9 , Hepes- $\mathrm{NaOH} 10, \mathrm{~d}-$ glucose 6 , pyruvate 2 , amino acids and vitamins ( $\mathrm{pH} 7.48,307 \mathrm{mOsm})$. For dye delivery, patch pipettes were fabricated from glass capillaries (G85150T-4, Harvard Apparatus, Edenbridge, UK) using a double stage vertical puller (PP-830, Narishige) and were filled with LY dissolved at $220 \mu \mathrm{M}$ (final concentration) in a $320 \mathrm{mOsm}$ intracellular solution containing (in $\mathrm{mM}$ ): $\mathrm{KCl} \mathrm{134,} \mathrm{NaCl} 4$, $\mathrm{MgCl}_{2}$ 1, HEPES 20, EGTA 10 (adjusted to $\mathrm{pH} 7.3$ with
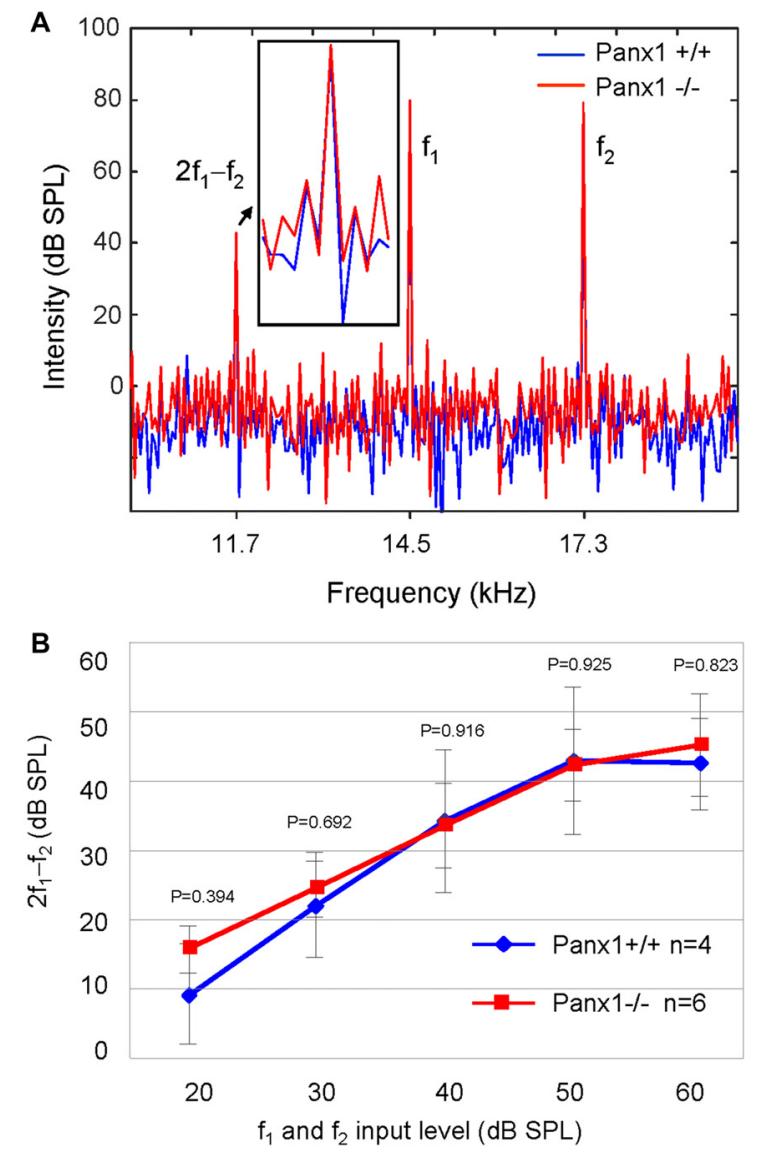

FIGURE 6 | Analysis of the $2 \mathrm{f}_{1}-\mathrm{f}_{2}$ cubic distortion product. (A) Representative spectra from WT (Panx1+/+, blue) and Panx1-/- mice (red) for a pair of $80 \mathrm{~dB}$ sound pressure level (SPL) primary frequencies $\left(f_{1}\right.$ and $\left.f_{2}\right)$; the inset shows a magnified view of the spectrum in the region of the $2 f_{1}-f_{2}$ cubic distortion product. (B) Growth function of the $2 f_{1}-f_{2}$ cubic distortion product; error bars represent SEM; $p$-values were determined by two-tail t-test.

$\mathrm{KOH}$ ) and filtered through $0.22 \mu \mathrm{m}$ pores (Millipore). Pipette resistances were 3-4 MOhm when immersed in the bath. One cell (donor) was patch clamped and maintained in the cell-attach configuration for a few seconds to establish a baseline. The patch of membrane under the pipette sealed to the donor cell was subsequently ruptured, allowing the LY to fill the cell, while leaving the seal intact (whole cell recording conditions). The cell was held at its zero current level using the current clamp configuration of the patch clamp amplifier (Axopatch 200B, Molecular devices). LY diffusion among (first order) cells adjacent to the injected cell was monitored over time by acquiring fluorescence images at a rate of 1 frame per second with a typical exposure time of $70 \mathrm{~ms}$. Fluorescence images were displayed as $\left(\mathrm{F}-\mathrm{F}_{\mathrm{bck}}\right) /\left(\mathrm{F}_{\max }-\mathrm{F}_{\mathrm{bck}}\right)$, where $\mathrm{F}_{\max }$ is the maximal value reached in the injected cell at the end of the recordin interval and $\mathrm{F}_{\mathrm{bck}}$ is autofluorescence. Experiments were performed at room temperature $\left(22-25^{\circ} \mathrm{C}\right)$. 


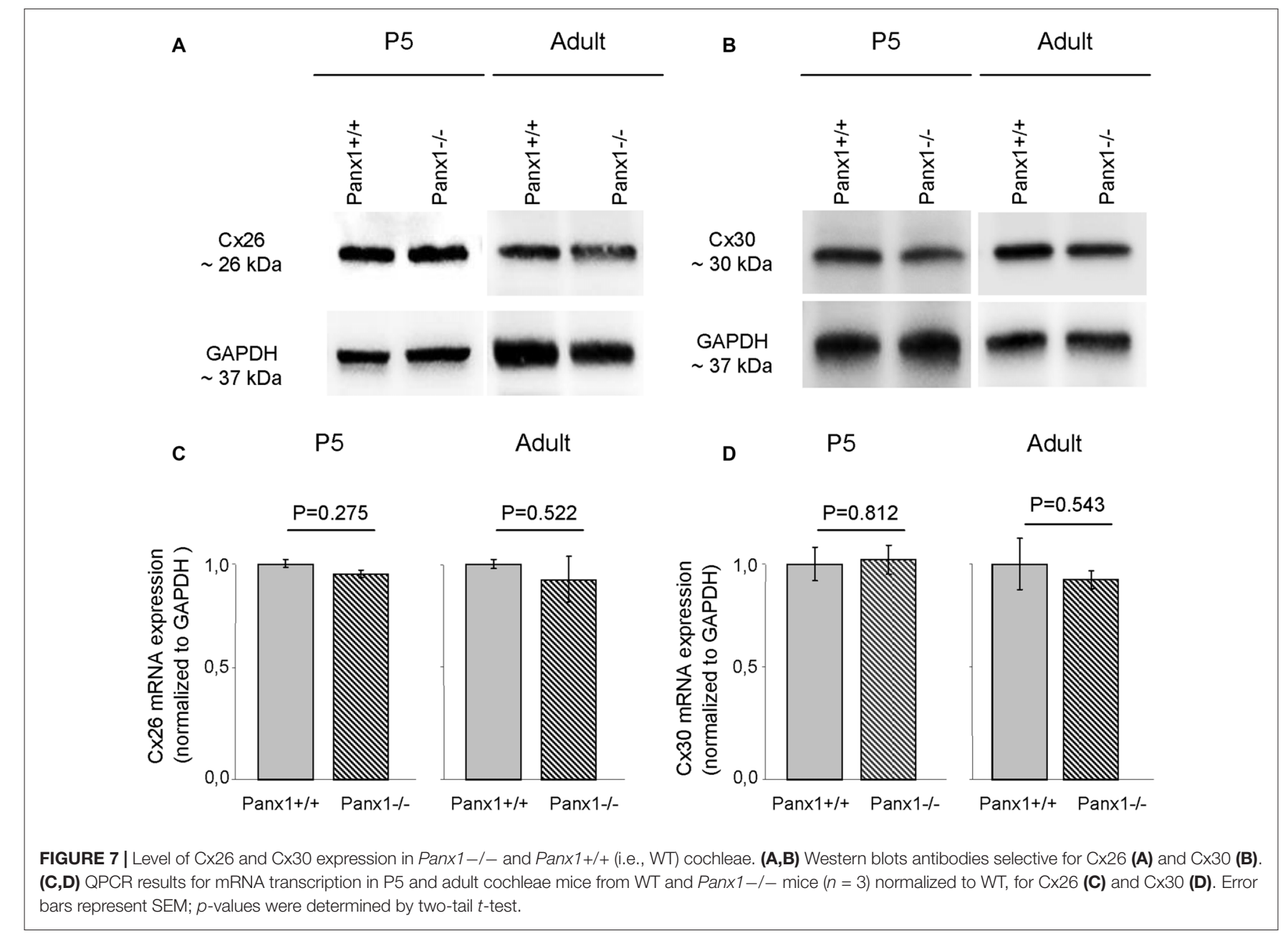

\section{Multiphoton Microscopy and $\mathrm{Ca}^{2+}$ Imaging in Cochlear Organotypic Cultures}

To record spontaneous intercellular $\mathrm{Ca}^{2+}$ signal (ICS) activity in nonsensory cells of the mouse cochlea, organotypic cultures of sensory epithelium were incubated for $45 \mathrm{~min}$ at $37^{\circ} \mathrm{C}$ in DMEM/F12 supplemented with the acetoxymethyl (AM) ester of the selective $\mathrm{Ca}^{2+}$ sensor Fluo-Forte $(16 \mu \mathrm{M}$, Enzo Life Science, \#ENZ-52014). The incubation medium contains also pluronic F-127 (0.1\% w/v, Sigma-Aldrich, \#P2443) and sulfinpyrazone (250 $\mu \mathrm{M}$, Sigma-Aldrich, \#S9509) to prevent dye sequestration and secretion. Cultures were then transferred to an upright microscope stage (see below) and continually perfused with EXM (see above) for $15 \mathrm{~min}$ at $1 \mathrm{ml} / \mathrm{min}$ in a dark environment at $25^{\circ} \mathrm{C}$ to allow for dye de-esterification. All subsequent imaging experiments were also performed at $25^{\circ} \mathrm{C}$.

To record $\mathrm{Ca}^{2+}$ signals, we used a two-photon microscope (Bergamo II, Thorlabs) equipped with a resonant scanner and coupled with a mode-locked Ti:Sapphire pulsed laser (Chameleon-Ultra II, Coherent). Fluo-Forte was excited at $940 \mathrm{~nm}$ by focusing the Ti:Sapphire beam onto the sample through a water-immersion objective (XLPlan N,
25× 1.05 NA, Olympus). Average power at the sample was $\sim 20 \mathrm{~mW}$. The fluorescence signal, collected by the same objective, was reflected towards the detection arm of the microscope by the $705 \mathrm{~nm}$ primary dichroic mirror of the microscope (Semrock, FF705-Di01), placed at $45^{\circ}$ above the objective. After traversing a $680 \mathrm{~nm}$ short pass filter (FF01-680/SP-25, Semrock) and $495 \mathrm{~nm}$ dichroic beam-splitter (T495lpxru, Chroma Technology), the Fluo-Forte signal was selected in the range $435-485 \mathrm{~nm}$ by a single band-pass filter (ET460/50m-2p, Chroma Technology) placed in front of a non-descanned GaAsP detector (H7422-50, Hamamatsu). Mechanical ultra-fast shutters were used to limit light exposure to the bear minimum required for image acquisition.

Sequences of $512 \times 512$ pixels frames were acquired, averaged in lots of nine and presented at a final rate of 5 per second. Illumination intensity, frame average, frame rate and the number of pixels in each frame were adjusted so as to minimize photobleaching and phototoxicity, while achieving sufficient signal to noise ratio and temporal resolution. Image sequences were acquired using ThorImage LS 3.1 software (Thorlabs). 


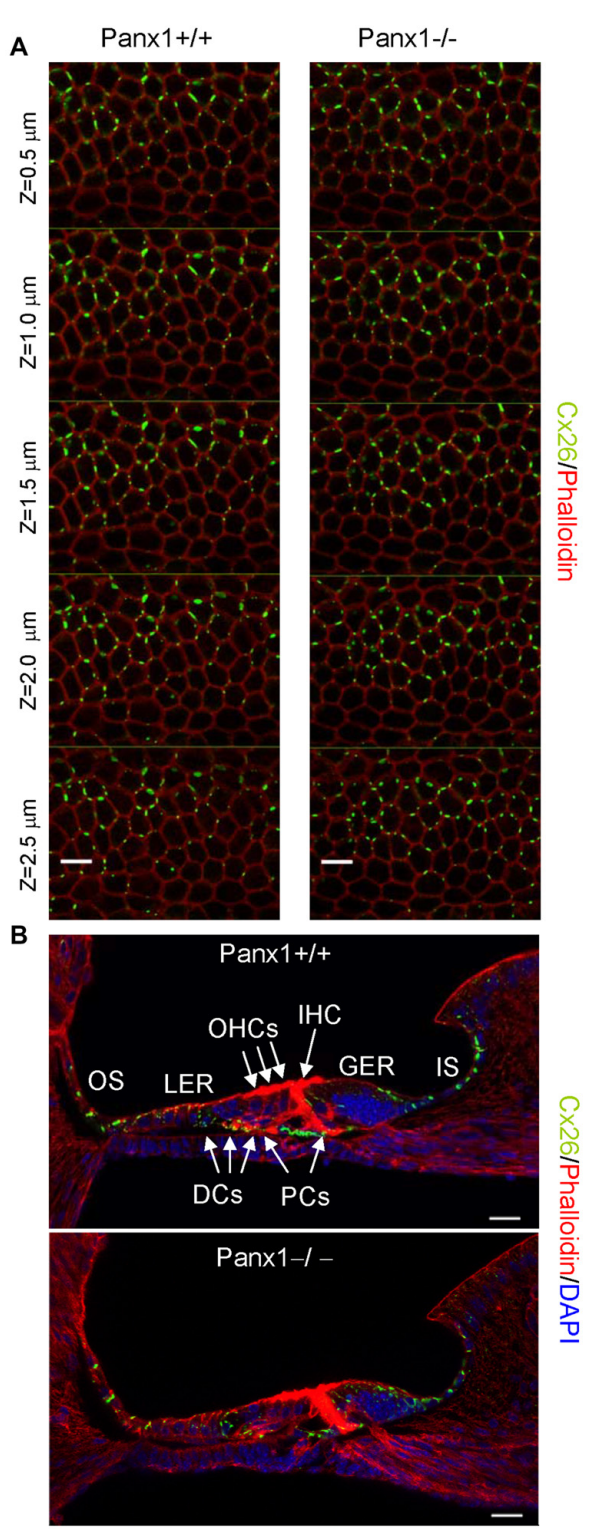

FIGURE 8 | Cx26 expression pattern in the sensory epithelium of Panx1+/+ (i.e., WT) and Panx1-/- cochleae from P5 mice. (A) Confocal through-focus sequence ( $z$-stack) acquired at $0.5 \mu \mathrm{m}$ increments showing Cx26 expression detected with a selective antibody (green) in epithelial cells of the LER counterstained with phalloidin (red); scale bars: $10 \mu \mathrm{m}$. (B) Representative transversal sections of the organ of Corti. Shown are maximal projection rendering of three consecutive midmodiolar confocal optical sections taken at $0.5 \mu \mathrm{m}$ intervals in the medial cochlear turn; nuclei were stained with DAPI (blue). IHC, inner hair cells; OHCs, outer hair cells; DCs, Deiters' cells; LER, lesser epithelial ridge; greater epithelial ridge (GER) greater epithelial ridge; PCs, Pillar cells; scale bars: $20 \mu \mathrm{m}$.

$\mathrm{Ca}^{2+}$ signals were quantified as pixel-by-pixel relative changes of fluorescence emission intensity, i.e., $\Delta F(t) / F_{0}$ where $t$ is time, $F(t)$ is fluorescence at time $t, F_{0}$ is the fluorescence at the onset of the recording and $\Delta F(t)=F(t)-F_{0}$. All data were processed off-line and presented using Vimmaging (F. Mammano and C. Ciubutaru, VIMM, Padova, Italy), a custom-made software routine developed under
MATLAB ${ }^{\mathrm{TM}}$ environment (The MathWorks Inc., Natick, MA, USA).

\section{RESULTS}

\section{Panx1 Is Absent in the Cochlea of Panx1-/- Mice}

Generation and genotyping of Panx1-/- mice were previously described (Anselmi et al., 2008; Bargiotas et al., 2011). Here we report an additional data set based on Panx1 expression analyses by RT-PCT and Western immunoblotting. Panx1 mRNA transcript expression was detected in the cochlea and brain of WT mice at both P5 and adult stage, but not in Panx1-/- mice (Figure 1). Consistent with these results, Western blots failed to reveal Panx1 expression in the cochlea of Panx1-/- mice at both $\mathrm{P} 5$ and in the adult stage, whereas bands with the correct molecular weight $(\sim 48 \mathrm{kDa})$ were present in Panx $1+/+$ (i.e., WT) extracts (Figure 2).

Using a previously validated antibody that targets an extracellular epitope of the Panx1 protein (AvesLab \#6358; Hanstein et al., 2013), we detected strong immunoreactivity in epithelial cells lining the endolymphatic surface of the sensory epithelium (inner sulcus, outer sulcus), supporting and epithelial cells of the organ of Corti, Reissner's membrane, and spiral ganglion neurons of WT mice. Weak immunostaining was also detected in the spiral limbus and spiral ligament of these mice, whereas the AvesLab \#6358 antibody failed to label cochlear tissue from Panx1-/mice (Figure 3). Altogether these results confirm successful ablation of Panx1 in the (brain and) cochlea of Panx1-/mice.

\section{ABRs and DPOAEs in Panx1-/- Mice Are Indistinguishable from WT Controls}

Next, we sought to corroborate and extend the results obtained by Anselmi et al. (2008) by analyzing in greater detail the hearing performance of Panx1-/- mice. In humans and mice alike, sound-evoked ABR potentials appear as a series of consecutive relative maxima (peaks), termed Waves and labeled with Roman numerals, which arise from the synchronous short-latency synaptic activity of successive nuclei along the peripheral afferent auditory neural pathway (Zheng et al., 1999; Legatt, 2002; Zhou et al., 2006). The first peak (Wave I) arises from the cochlea and/or compound action potential of the auditory nerve $\sim 1 \mathrm{~ms}$ after the stimulus onset (latency). Waves from II to $\mathrm{V}$ originate from cochlear nuclei, contralateral superior olivary complex, lateral lemniscus and contralateral lateral inferior colliculus. For reference, Table I of Scimemi et al. (2014) presents means and standard deviations (SD) of latency and amplitude values of $A B R$ peaks $I-V$ for C57BL/6 mice.

Hearing threshold estimates from click and pure-tone ABR analysis, as well as latency and amplitude of Wave I and Wave II in PanxI-/- mice aged between P30 and P90, were indistinguishable from those of 

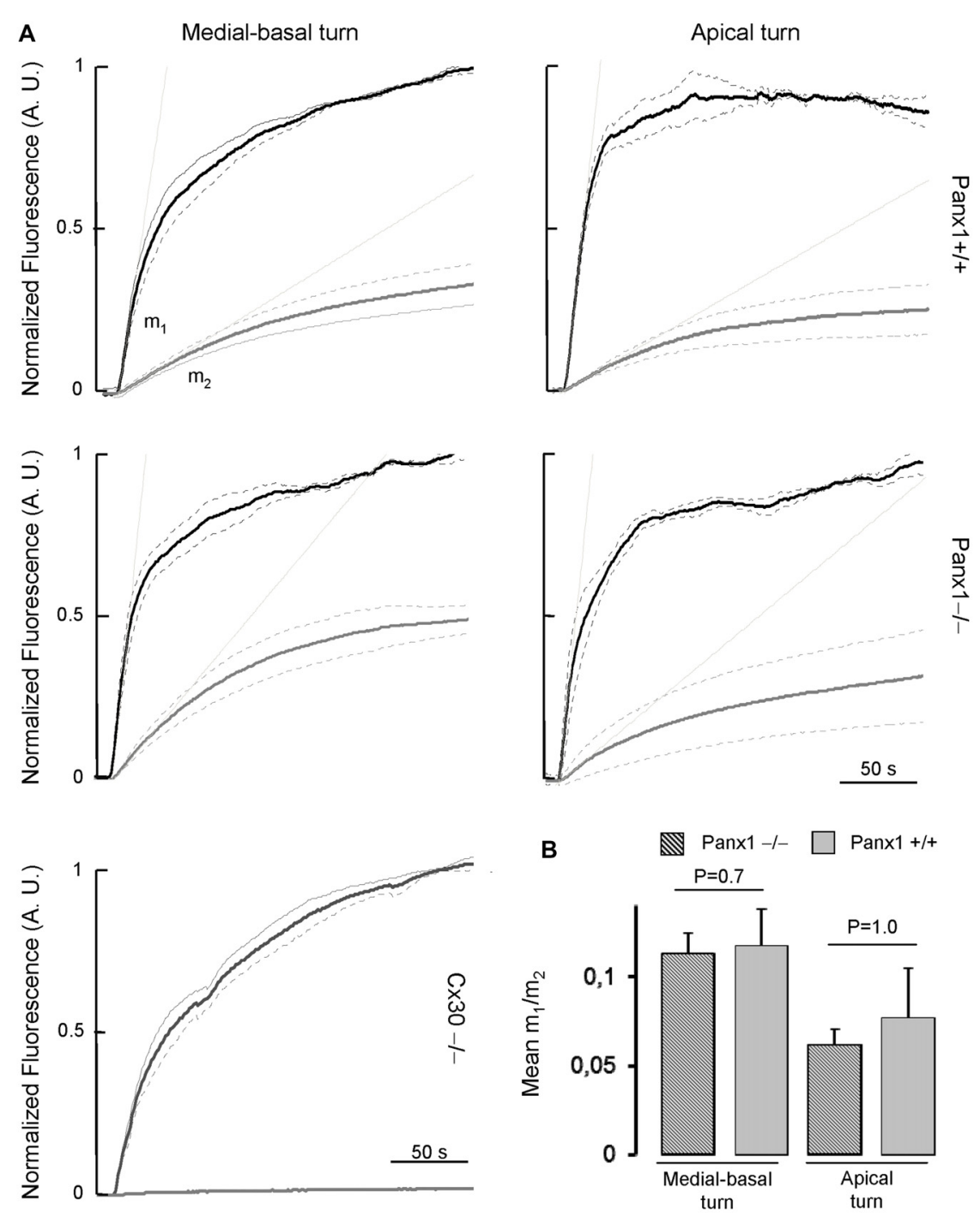

FIGURE 9 | (A) Lucifer yellow fluorescence emission averaged over the cell body of (first order) cells (gray solid lines, $n=5$ ) adjacent to the injected cell and normalized to the maximal fluorescence emission detected in the injected cell (black solid lines); data are mean values \pm SEM (dot lines) for $n=8$ cells in each condition. (B) For each experiment, the interpolating line of the curve related to first order cells (with computed slope $m_{2}$ ) and to the injected cell (with computed slope $m_{1}$ ) was computed over the first $10 \mathrm{~s}$ of recording. Histograms show mean values of the ratio between $m_{2}$ and $m_{1}$ for WT (Pan $+/+$, dashed bars) and Panx1-/- mice (filled bars). Error bars represent SEM.

age-matched Panx1+/- and WT control mice (Figures 4, 5, Tables 1-5).

Sound generated within the mammalian inner ear as a reflection of outer hair cell (OHC) mechanical activity (Nobili and Mammano, 1996; Nobili et al., 2003) can be detected with a sensitive microphone placed in the auditory meatus (Kemp, 1978, 2002). Therefore, as a further non-invasive indicator of cochlear function, we measured the cubic $\left(2 \mathrm{f}_{1}-\mathrm{f}_{2}\right)$ DPOAE (see "Materials and Methods" section) and found no significant differences in the DPOAE growth function of Panx1-/- mice and age-matched WT controls (Figure 6).

Altogether, these results indicate absence of detectable defects in auditory function of Panx $1-/-$ mice. This conclusion is based on their normal hearing sensitivity, normal function of the outer hair cell-based "cochlear amplifier" (Frolenkov et al., 1998; Nobili et al., 1998; Ashmore, 2008) and absence of cochlear nerve defects.

\section{Connexin Expression and Function Is Normal in Panx1-/- Mice}

Pannexins bear significant sequence homology with the invertebrate gap junction proteins, innexins, and more distant similarities in their membrane topologies and pharmacological sensitivities with the gap junction proteins, connexins (Sosinsky et al., 2011).

Non-sensory cells of the mammalian cochlea express two closely related gap junction proteins, connexin 26 (Cx26) and 
A

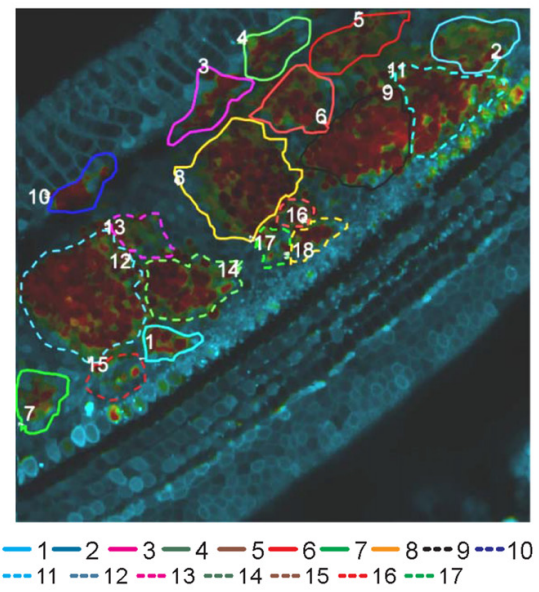

B

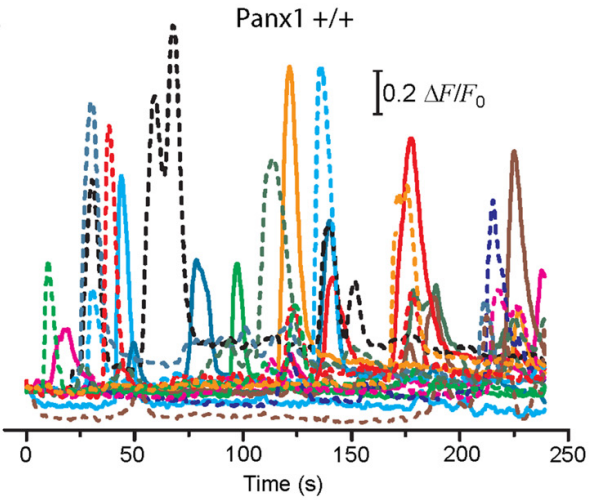

C

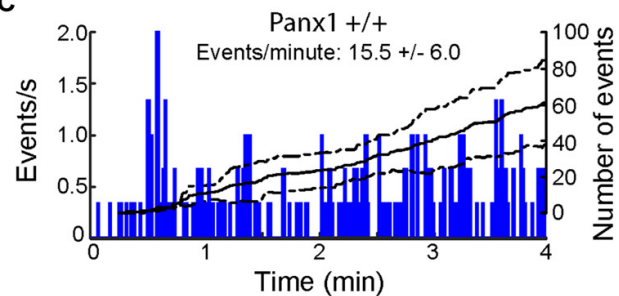

D

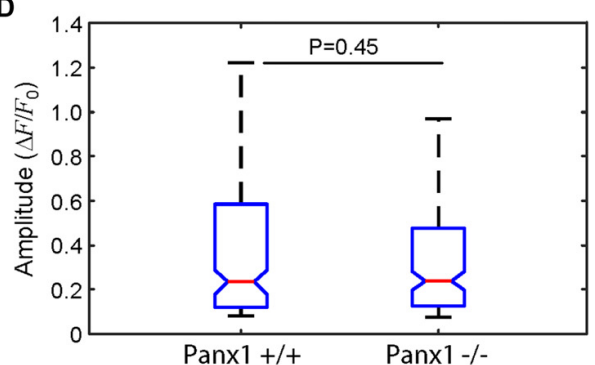

Panx1 -/-

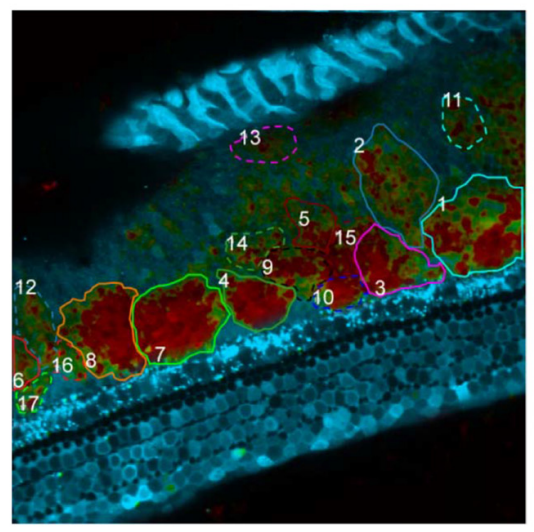

$-1-2-3-4-5-6-7-8---9---10$

--- 11 --- 12 ---13 ---14 --- 15 ---16 --- 17

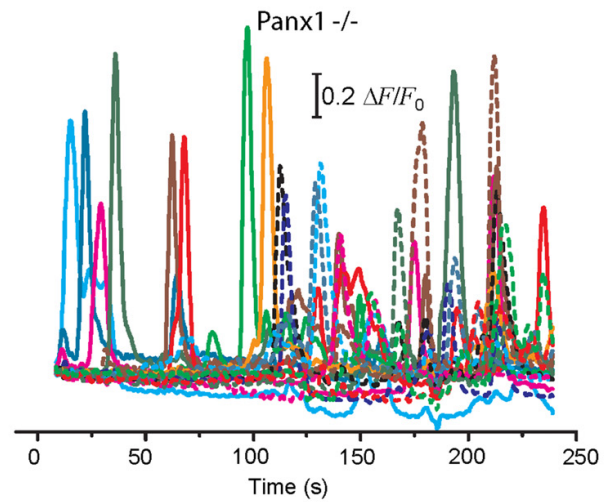

Panx 1 -/-

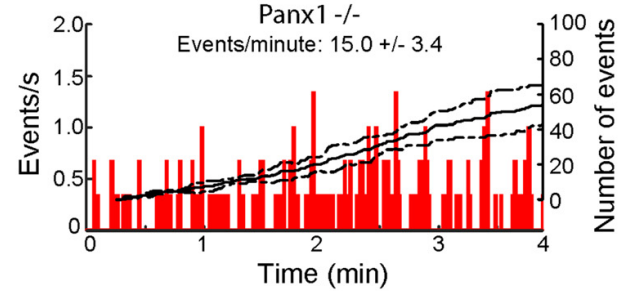

E

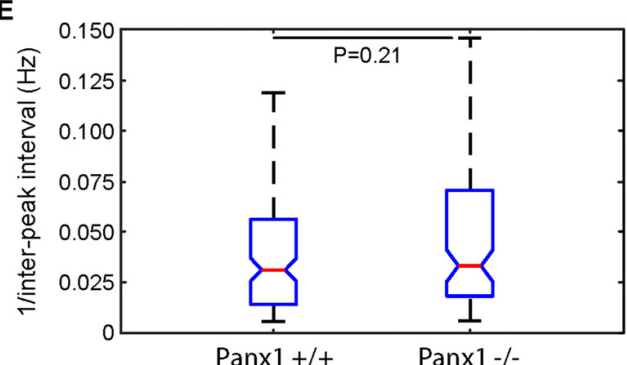

FIGURE 10 | Spontaneous cytosolic $\mathrm{Ca}^{2+}$ transients in the GER of WT (Pan $\left.x+/+\right)$ and Panx $1-/-$ postnatal cochlear cultures. (A) Representative false-color images of Fluo-Forte fluorescence changes $\left(\Delta F / F_{0}\right)$, encoded as shown by the color scale bar, obtained as maximal projection rendering of all frames recorded in an apical-middle turn culture from a P5 mouse imaged for 4 min at 5 frames per second; regions of interests are shown superimposed on different GER areas invaded by spontaneous $\mathrm{Ca}^{2+}$ waves. Scale bar, $50 \mu \mathrm{m}$. (B) Fluo-forte traces generated as pixel averages from the color-matched regions of interests shown in (A). (C) Frequency histograms of spontaneous cytosolic $\mathrm{Ca}^{2+}$ transients (events) in cultures from P5 Panx+/+ and Panx1-/- mice (pooled data). (D) Distributions of events amplitude $\left(\Delta F_{\max } / F_{0}\right)$, from data in (C). The values of the median and inter-quartile range (IQR) are, respectively: 0.2340 and $0.4641(P a n x+/+) ; 0.2398$ and 0.3501 (Panx1-/-). (E) Distributions of the frequency (i.e., the reciprocal of the inter-peak interval) between consecutive events from data in (C). The values of the median and IQR are, respectively (in Hz): 0.0312 and 0.0420 (Panx+/+); 0.0331 and 0.0520 (Panx1-/-). P-values in (C,D) were computed with the Mann-Whitney $U$ test. 
connexin 30 (Cx30; Lautermann et al., 1998; Ahmad et al., 2003; Forge et al., 2003; Zhao et al., 2006), the expression of which is coordinately regulated (Ortolano et al., 2008). Mouse models indicate that altered expression levels of these connexins in the early postnatal days impacts on organ of Corti development and hair cell maturation (Johnson et al., 2017), preventing normal hearing acquisition (Cohen-Salmon et al., 2002; Teubner et al., 2003; Ahmad et al., 2007; Sun et al., 2009; Crispino et al., 2011, 2017; Qu et al., 2012; Zhu et al., 2013). As regulatory mechanism may potentially be shared between connexins and pannexins, we examined the expression of $\mathrm{Cx} 26$ and $\mathrm{Cx} 30$ by Western blot analysis and QPCR, and found no significant differences between Panx1-/- mice and age-matched WT controls (Figure 7). The spatial distribution of Cx26 at P5 was investigated also by immunofluorescence and, again, no differences between Panx1-/- mice and age-matched WT controls were detected (Figure 8).

To assess whether the expressed connexins confer cell-tocell connectivity, we quantified dye transfer in the LER of organotypic cochlear cultures from P5 mice (see "Materials and Methods" section). To gauge transfer rate, we measured the slope of the LY fluorescence growth function at the onset of dye delivery in the donor cell $\left(m_{1}\right)$ and in its nearest neighbors $\left(m_{2}\right)$, and found no significant differences in the $m_{2} / m_{1}$ ratio of Panx1-/- mice and WT controls (Figure 9).

Altogether the results presented in Figures 7-9 indicate that lack of Panx1 in Panx1-/- mice impacts neither on connexins expression, nor on gap-junction coupling in the developing organ of Corti.

\section{Spontaneous $\mathrm{Ca}^{2+}$ Signaling Activity Is Normal in the Developing Cochlea of Panx1-/- Mice}

Connexins play a crucial development role in the postnatal cochlea (as mentioned above), also by supporting ICS activity both in the LER (Beltramello et al., 2005; Piazza et al., 2007; Anselmi et al., 2008; Majumder et al., 2010; Ceriani et al., 2016) and in the greater epithelial ridge (GER; Tritsch et al., 2007; Schütz et al., 2010; Rodriguez et al., 2012; Wang and Bergles, 2015; Johnson et al., 2017; Mammano and Bortolozzi, 2017). Using focal ATP delivery or photostimulation with caged $\mathrm{IP}_{3}$, Anselmi et al. (2008) showed ICS failure in cultures with deficient expression of Cx26 and Cx30, whereas ICS in organotypic cultures from Panx1-/- mice was indistinguishable from those of WT controls.

Here, we used multiphoton microscopy to monitor spontaneous ICS activity (Tritsch et al., 2007; Schütz et al., 2010; Rodriguez et al., 2012; Wang and Bergles, 2015; Johnson et al., 2017; Mammano and Bortolozzi, 2017) in organotypic cochlear cultures from P5 mice loaded with the $\mathrm{Ca}^{2+}$ indicator Fluo Forte AM (Mammano and Bortolozzi, 2017). Specifically, we examined the frequency of occurrence of spontaneous $\mathrm{Ca}^{2+}$ transients (events) in the apical cochlear turn by counting all occurrences within the portion of the GER in the field view from P5 Panx1-/- mice and age-matched WT siblings (Figure 10). We found a similar mean frequencies of occurrence $(15.5 \pm 6.0$ events/min in Panx1+/+ vs. $15.0 \pm 3.4$ events/min in Panx1-/- cultures). Likewise, amplitude and inter-peak interval distributions of spontaneous $\mathrm{Ca}^{2+}$ transients of Panx1-/- cultures overlapped with those of Panx1+/+ cultures. Altogether, these results indicate that spontaneous ICS activity in the GER of the postnatal cochlea is not affected by Panx1 ablation.

\section{DISCUSSION}

The Panx1-/- strain we have analyzed was the first with a reported global ablation of Panx1 (Anselmi et al., 2008; Bargiotas et al., 2011). The present results confirm successful ablation of Panx1 in Panx1-/- mice, while our ABR and DPOAE data indicate normal hearing sensitivity, normal function of the outer hair cell-based "cochlear amplifier" (Frolenkov et al., 1998; Nobili et al., 1998; Ashmore, 2008) and absence of cochlear nerve defects, in agreement with the initial observation that Pan $x 1-/-$ mice do not exhibit a detectable hearing phenotype (Anselmi et al., $2008^{8}$ ).

We also confirmed that lack of Panx1 affects neither the expression of inner ear connexins nor gap junction communication in the organ of Corti. Furthermore, our experiments with cochlear organotypic cultures indicate that the ATP-release mechanism underlying the spontaneous ICS activity of cells in the GER is intact. Preservation of this mechanism is essential for hearing acquisition (Schütz et al., 2010; Rodriguez et al., 2012; Mammano and Bortolozzi, 2017) and maturation of sensory hair cells (Johnson et al., 2017). Recent results with a monoclonal antibody that inhibits Cx26 hemichannels substantiate the notion that, in the cochlear sensory epithelium, ATP is released from such hemichannels (Xu et al., 2017).

Ensuring that an allele derived from the tmla cassette is a full null, rather that a hypomorph such as the Panx $1^{\text {tmla(KOMP)Wtsi }}$ strain, and alleviating potential off-target gene mis-regulation, requires modification of tmla, which can be performed in embryonic stem (ES) cells or in crosses with transgenic Flp and Cre mice. Flp deletion converts tmla to a conditional allele $(\mathrm{tm} 1 \mathrm{c})$, restoring gene activity, whereas the promoterdriven selection cassette and floxed exon of the tmla allele can be deleted by Cre to generate a lacZ-tagged allele (tm1b; Skarnes et al., 2011). This is usually accomplished by breeding the mice to a source of Cre expressed in the germline, followed by outcrossing and selection of knockout offspring that fail to carry the Cre driver (Skarnes et al., 2011). This was also the strategy followed by the International Mouse Phenotyping Consortium (IMPC ${ }^{9}$ Brown and Moore,

\footnotetext{
${ }^{8} \mathrm{http}: / /$ www.informatics.jax.org/marker/phenotypes/MGI:1860055
}

${ }^{9}$ http://www.mousephenotype.org/ 
2012) to convert the tmla allele to tm $1 b$ for subsequent phenotyping (Ryder et al., 2014). The Panx $1^{\text {tmlb(KOMP)Wtsi }}$ strain generated in this way was analyzed by the IMPC and reported to have no significant hearing/vestibular phenotype ${ }^{10}$.

Thus, altogether, our results and conclusions are consistent with hearing assessments both in the Genentech-Panx1-/strain (Abitbol et al., 2016) and in the Panx $1^{\text {tmlb(KOMP)Wtsi }}$ strain generated and analyzed by the IMPC.

The lack of any measurable auditory phenotype in three strains, which are all global knockouts of Panx1, is in stark contrast with the phenotype reported for Pax2-cPanx1-/(Zhao et al., 2015), and even more so for Foxg1-cPanx1-/mice that, despite descending from the hypomorphic Pan $x 1^{\text {tmla(KOMP)Wtsi }}$ strain, retained strong immunoreactivity for the Panx1 \#4515 chicken anti-human antibody (which is not specific: Bargiotas et al., 2011; see "Introduction" section) in the organ of Corti and the spiral limbus (Chen et al., 2015). However, it should be considered that both the Pax2-cPanx1-/and the Foxg1-cPanx1-/- strain must necessarily express a Cre recombinase (Friedel et al., 2011), whereas the three global knockout strains mentioned above do not express Cre. It is well known that Cre expression in mammalian cells can induce chromosomal aberrations and toxicity that is dependent on the level of Cre activity (Loonstra et al., 2001). Indeed, Caspase-3 activation and cell degeneration are reported hallmarks of the organ of Corti in Pax2-cPanx1-/- mice (Zhao et al., 2015). Furthermore, Foxg $1^{\text {Cre }}$ mice that are homozygous for the targeted mutation die perinatally (Tian et al., 2012 ${ }^{11}$ ), whereas heterozygous $G f i 1^{\mathrm{Cre}}$ mice, one of the many driver lines used for conditional cell-specific gene deletion/reporter gene activation in the inner ear (Cox et al., 2012), were recently reported with an early onset progressive hearing loss, which was absent in their wild-type littermates (Matern et al., 2017).

Another risk factor that is worth considering is related to the structure of the tmla selection cassette (Testa et al., 2004; Skarnes et al., 2011) used to generate the hypomorphic Panx $1^{\text {tmla(KOMP)Wtsi }}$ mice. As the latter were not crossed with a Flp deleter line before being used to create Pax2-cPanx1-/- and Foxg1-cPanx1-/- mice, it is not clear from the data provided if the Cre-mediated deletion removed only exon 2 of Panx1 or also the neo cassette, nor from which tissue the sample tested was obtained.

It is well known that retention of a neo cassette can cause unexpected phenotypes in "knockout" mice due to neighborhood effects (Pham et al., 1996; Scacheri et al., 2001; Ren et al., 2002; Meier et al., 2010). Indeed, removal of the neo cassette and critical exon from the tmla allele is regarded as an essential procedure that alleviates potential off-target gene mis-regulation caused by the neo promoter, and to ensure that the allele is a full null rather then a hypomorph (Skarnes et al., 2011).

\footnotetext{
${ }^{10}$ www.mousephenotype.org/data/genes/MGI:1860055\#section-associations

${ }^{11} \mathrm{http}: / /$ jaxmice.jax.org/strain/004337.html
}

In this vein, it was recently argued that the hearing loss phenotype exhibited by Cx30-/- mice (Teubner et al., 2003) depends on the cumulative effect of deletion of $C \times 30$ and 3 ' insertion of a lac $Z$ and neo cassette. Indeed, in a strictly related knockout mouse model $(C \times 30 \Delta / \Delta)$ in which $C \times 30$ was removed without perturbing the surrounding sequences, hearing thresholds determined by ABR analysis are normal (Boulay et al., 2013; Crispino et al., 2017).

In conclusion, our extended characterization of Panx1-/mice provides strong evidence that Panx1 is dispensable for hearing acquisition and auditory function.

\section{DATA AND CODE AVAILABILITY}

Data and computer code used to analyze data are available from the authors upon request.

\section{AUTHOR CONTRIBUTIONS}

FaM designed the studies, provided resources to conduct the studies and wrote the manuscript; HM provided Panx1-/mice and genotyping protocols; VZ, MP and FC performed animal genotyping; $M R$ and FS were in charge of animal welfare and performed quality controls; VZ and FP performed in vivo electrophysiology; $\mathrm{AC}$ wrote software code to filter $\mathrm{ABR}$ waveforms; CDC wrote image acquisition and analysis software; $\mathrm{VZ}, \mathrm{FP}$ and $\mathrm{CN}$ analyzed ABR and DPOAE data; VZ performed immunofluorescence studies; FP performed Western blot analyses; VZ and GZ generated organotypic cochlear cultures; GZ performed patch clamp, dye transfer in cochlear organotypic cultures and analyzed data; CP and FlM performed multiphoton microscopy and $\mathrm{Ca}^{2+}$ imaging in cochlear organotypic cultures, and analyzed data; AMS, ARF and FaM supervised the work of junior colleagues; VZ, GC, FC, FS, ARF and AMS edited the text.

\section{FUNDING}

This work was supported by Consiglio Nazionale delle Ricerche (CNR) Progetto di Interesse Invecchiamento (grant DSB. AD009.001.004/INVECCHIAMENTO-IBCN) and Fondazione Telethon (grant GGP13114) to FaM.

\section{ACKNOWLEDGMENTS}

The AvesLab \#6358 antibody used in this study was a gift of Prof. Eliana Scemes (Dominick P. Purpura Department of Neuroscience, Kennedy Center, Albert Einstein College of Medicine, Bronx, NY, USA). The authors thank E. Perlas of EMBL-Rome Histology Facility and G. Bolasco of EMBL_-Rome Microscopy Facility for assistance with histology and microscopy; I. Losso of EMMA-INFRAFRONTIER Monterotondo for technical assistance. 


\section{REFERENCES}

Abitbol, J. M., Kelly, J. J., Barr, K., Schormans, A. L., Laird, D. W., and Allman, B. L. (2016). Differential effects of pannexins on noise-induced hearing loss. Biochem. J. 473, 4665-4680. doi: 10.1042/bcj20160668

Ahmad, S., Chen, S., Sun, J., and Lin, X. (2003). Connexins 26 and 30 are co-assembled to form gap junctions in the cochlea of mice. Biochem. Biophys. Res. Commun. 307, 362-368. doi: 10.1016/s0006-291x(03)01166-5

Ahmad, S., Tang, W., Chang, Q., Qu, Y., Hibshman, J., Li, Y., et al. (2007). Restoration of connexin 26 protein level in the cochlea completely rescues hearing in a mouse model of human connexin30-linked deafness. Proc. Natl. Acad. Sci. U S A 104, 1337-1341. doi: 10.1073/pnas.0606855104

Anselmi, F., Hernandez, V. H., Crispino, G., Seydel, A., Ortolano, S., Roper, S. D., et al. (2008). ATP release through connexin hemichannels and gap junction transfer of second messengers propagate $\mathrm{Ca}^{2+}$ signals across the inner ear. Proc. Natl. Acad. Sci. U S A 105, 18770-18775. doi: 10.1073/pnas.0800793105

Ashmore, J. (2008). Cochlear outer hair cell motility. Physiol. Rev. 88, 173-210. doi: 10.1152/physrev.00044.2006

Baranova, A., Ivanov, D., Petrash, N., Pestova, A., Skoblov, M., Kelmanson, I., et al. (2004). The mammalian pannexin family is homologous to the invertebrate innexin gap junction proteins. Genomics 83, 706-716. doi: 10.1016/j.ygeno. 2003.09.025

Bargiotas, P., Krenz, A., Hormuzdi, S. G., Ridder, D. A., Herb, A., Barakat, W., et al. (2011). Pannexins in ischemia-induced neurodegeneration. Proc. Natl. Acad. Sci. U S A 108, 20772-20777. doi: 10.1073/pnas.1018262108

Beltramello, M., Piazza, V., Bukauskas, F. F., Pozzan, T., and Mammano, F. (2005). Impaired permeability to Ins $(1,4,5) \mathrm{P} 3$ in a mutant connexin underlies recessive hereditary deafness. Nat. Cell Biol. 7, 63-69. doi: 10.1038/ncb1205

Boulay, A., del Castillo, F. J., Giraudet, F., Hamard, G., Giaume, C., Petit, C., et al. (2013). Hearing is normal without connexin30. J. Neurosci. 33, 430-434. doi: 10.1523/jneurosci.4240-12.2013

Bredenkamp, N., Seoighe, C., and Illing, N. (2007). Comparative evolutionary analysis of the FoxG1 transcription factor from diverse vertebrates identifies conserved recognition sites for microRNA regulation. Dev. Genes Evol. 217, 227-233. doi: 10.1007/s00427-006-0128-x

Brown, S. D., and Moore, M. W. (2012). The international mouse phenotyping consortium: past and future perspectives on mouse phenotyping. Mamm. Genome 23, 632-640. doi: 10.1007/s00335-012-9427-x

Bruzzone, R., Hormuzdi, S. G., Barbe, M. T., Herb, A., and Monyer, H. (2003). Pannexins, a family of gap junction proteins expressed in brain. Proc. Natl. Acad. Sci. U S A 100, 13644-13649. doi: 10.1073/pnas.2233464100

Ceriani, F., Pozzan, T., and Mammano, F. (2016). Critical role of ATP-induced ATP release for $\mathrm{Ca}^{2+}$ signaling in nonsensory cell networks of the developing cochlea. Proc. Natl. Acad. Sci. U S A 113, E7194-E7201. doi: 10.1073/pnas. 1616061113

Chen, J., Zhu, Y., Liang, C., Chen, J., and Zhao, H. B. (2015). Pannexin1 channels dominate ATP release in the cochlea ensuring endocochlear potential and auditory receptor potential generation and hearing. Sci. Rep. 5:10762. doi: $10.1038 /$ srep 10762

Cohen-Salmon, M., Ott, T., Michel, V., Hardelin, J. P., Perfettini, I., Eybalin, M., et al. (2002). Targeted ablation of connexin26 in the inner ear epithelial gap junction network causes hearing impairment and cell death. Curr. Biol. 12, 1106-1111. doi: 10.1016/s0960-9822(02)00904-1

Cohen-Salmon, M., Regnault, B., Cayet, N., Caille, D., Demuth, K., Hardelin, J. P., et al. (2007). Connexin30 deficiency causes instrastrial fluid-blood barrier disruption within the cochlear stria vascularis. Proc. Natl. Acad. Sci. U S A 104, 6229-6234. doi: 10.1073/pnas.0605108104

Cone, A. C., Ambrosi, C., Scemes, E., Martone, M. E., and Sosinsky, G. E. (2013). A comparative antibody analysis of pannexin 1 expression in four rat brain regions reveals varying subcellular localizations. Front. Pharmacol. 4:6. doi: 10.3389/fphar.2013.00006

Cox, B. C., Liu, Z., Lagarde, M. M., and Zuo, J. (2012). Conditional gene expression in the mouse inner ear using Cre-loxP. J. Assoc. Res. Otolaryngol. 13, 295-322. doi: 10.1007/s10162-012-0324-5

Crispino, G., Di Pasquale, G., Scimemi, P., Rodriguez, L., Galindo Ramirez, F., De Siati, R. D., et al. (2011). BAAV mediated GJB2 gene transfer restores gap junction coupling in cochlear organotypic cultures from deaf Cx26Sox10Cre mice. PLoS One 6:e23279. doi: 10.1371/journal.pone.0023279
Crispino, G., Galindo Ramirez, F., Campioni, M., Zorzi, V., Praetorius, M., Di Pasquale, G., et al. (2017). In vivo genetic manipulation of inner ear connexin expression by bovine adeno-associated viral vectors. Sci. Rep. 7:6567. doi: 10.1038/s41598-017-06759-y

Dahl, G., Qiu, F., and Wang, J. (2013). The bizarre pharmacology of the ATP release channel pannexin1. Neuropharmacology 75, 583-593. doi: 10.1016/j. neuropharm.2013.02.019

Dahl, G., and Muller, K. J. (2014). Innexin and pannexin channels and their signaling. FEBS Lett. 588, 1396-1402. doi: 10.1016/j.febslet.2014. 03.007

del Hierro, M. J., Fernandez, J., Castrillo, M., Martin-Dorado, I., Montoliu, L., Hagn, M., et al. (2016). EMMA: the european mouse mutant archive. Transgenic Res. 25, 228-228. Accession Number: WOS:000371155900078

Esseltine, J. L., and Laird, D. W. (2016). Next-generation connexin and pannexin cell biology. Trends Cell Biol. 26, 944-955. doi: 10.1016/j.tcb.2016. 06.003

Forge, A., Becker, D., Casalotti, S., Edwards, J., Marziano, N., and Nevill, G. (2003). Gap junctions in the inner ear: comparison of distribution patterns in different vertebrates and assessement of connexin composition in mammals. J. Comp. Neurol. 467, 207-231. doi: 10.1002/cne.10916

Friedel, R. H., Wurst, W., Wefers, B., and Kuhn, R. (2011). Generating conditional knockout mice. Methods Mol. Biol. 693, 205-231. doi: 10.1007/978-1-60761974-1_12

Frolenkov, G. I., Atzori, M., Kalinec, F., Mammano, F., and Kachar, B. (1998). The membrane-based mechanism of cell motility in cochlear outer hair cells. Mol. Biol. Cell 9, 1961-1968. doi: 10.1091/mbc.9.8.1961

Hanstein, R., Negoro, H., Patel, N. K., Charollais, A., Meda, P., Spray, D. C., et al. (2013). Promises and pitfalls of a Pannexin1 transgenic mouse line. Front. Pharmacol. 4:61. doi: 10.3389/fphar.2013.00061

Hébert, J. M., and McConnell, S. K. (2000). Targeting of cre to the Foxg1 (BF-1) locus mediates loxP recombination in the telencephalon and other developing head structures. Dev. Biol. 222, 296-306. doi: 10.1006/dbio. 2000.9732

Huang, Y. J., Maruyama, Y., Dvoryanchikov, G., Pereira, E., Chaudhari, N., and Roper, S. D. (2007). The role of pannexin 1 hemichannels in ATP release and cell-cell communication in mouse taste buds. Proc. Natl. Acad. Sci. U S A 104, 6436-6441. doi: 10.1073/pnas.0611280104

International Mouse Knockout Consortium, Collins, F. S., Rossant, J., and Wurst, W. (2007). A mouse for all reasons. Cell 128, 9-13. doi: 10.1016/j.cell. 2006.12.018

Johnson, S. L., Ceriani, F., Houston, O., Polishchuk, R., Polishchuk, E., Crispino, G., et al. (2017). Connexin-mediated signaling in nonsensory cells is crucial for the development of sensory inner hair cells in the mouse cochlea. J. Neurosci. 37, 258-268. doi: 10.1523/jneurosci.2251-16.2017

Kemp, D. T. (1978). Stimulated acoustic emissions from within the human auditory system. J. Acoust. Soc. Am. 64, 1386-1391. doi: 10.1121/1. 382104

Kemp, D. T. (2002). Otoacoustic emissions, their origin in cochlear function, and use. Br. Med. Bull. 63, 223-241. doi: 10.1093/bmb/63.1.223

Kranz, K., Dorgau, B., Pottek, M., Herrling, R., Schultz, K., Bolte, P., et al. (2013). Expression of Pannexin1 in the outer plexiform layer of the mouse retina and physiological impact of its knockout. J. Comp. Neurol. 521, 1119-1135. doi: $10.1002 /$ cne.23223

Kurtenbach, S., Kurtenbach, S., and Zoidl, G. (2014). Emerging functions of pannexin 1 in the eye. Front. Cell. Neurosci. 8:263. doi: 10.3389/fncel.2014. 00263

Lautermann, J., ten Cate, W. J., Altenhoff, P., Grümmer, R., Traub, O., Frank, H., et al. (1998). Expression of the gap-junction connexins 26 and 30 in the rat cochlea. Cell Tissue Res. 294, 415-420. doi: 10.1007/s004410051192

Legatt, A. D. (2002). Mechanisms of intraoperative brainstem auditory evoked potential changes. J. Clin. Neurophysiol. 19, 396-408. doi: 10.1097/00004691200210000-00003

Loonstra, A., Vooijs, M., Beverloo, H. B., Allak, B. A., van Drunen, E., Kanaar, R., et al. (2001). Growth inhibition and DNA damage induced by Cre recombinase in mammalian cells. Proc. Natl. Acad. Sci. U S A 98, 9209-9214. doi: 10.1073/pnas.161269798

Majumder, P., Crispino, G., Rodriguez, L., Ciubotaru, C. D., Anselmi, F., Piazza, V., et al. (2010). ATP-mediated cell-cell signaling in the organ 
of Corti: the role of connexin channels. Purinergic Signal. 6, 167-187. doi: 10.1007/s11302-010-9192-9

Mammano, F., and Bortolozzi, M. (2017). $\mathrm{Ca}^{2+}$ signaling, apoptosis and autophagy in the developing cochlea: milestones to hearing acquisition. Cell Calcium doi: 10.1016/j.ceca.2017.05.006 [Epub ahead of print].

Matern, M., Vijayakumar, S., Margulies, Z., Milon, B., Song, Y., Elkon, R., et al. (2017). GfilCre mice have early onset progressive hearing loss and induce recombination in numerous inner ear non-hair cells. Sci. Rep. 7:42079. doi: $10.1038 /$ srep42079

Meier, I. D., Bernreuther, C., Tilling, T., Neidhardt, J., Wong, Y. W., Schulze, C., et al. (2010). Short DNA sequences inserted for gene targeting can accidentally interfere with off-target gene expression. FASEB J. 24, 1714-1724. doi: 10.1096/fj.09-140749

Nobili, R., and Mammano, F. (1996). Biophysics of the cochlea. II: stationary nonlinear phenomenology. J. Acoust. Soc. Am. 99, 2244-2255. doi: 10.1121/1. 415412

Nobili, R., Mammano, F., and Ashmore, J. (1998). How well do we understand the cochlea? Trends Neurosci. 21, 159-167. doi: 10.1016/S0166-2236(97)01192-2

Nobili, R., Vetesnik, A., Turicchia, L., and Mammano, F. (2003). Otoacoustic emissions from residual oscillations of the cochlear basilar membrane in a human ear model. J. Assoc. Res. Otolaryngol. 4, 478-494. doi: 10.1007/s10162002-3055-1

Ohyama, T. (2009). Unraveling inner ear induction by gene manipulation using Pax2-Cre BAC transgenic mice. Brain Res. 1277, 84-89. doi: 10.1016/j.brainres. 2009.02.036

Ortolano, S., Di Pasquale, G., Crispino, G., Anselmi, F., Mammano, F., and Chiorini, J. A. (2008). Coordinated control of connexin 26 and connexin 30 at the regulatory and functional level in the inner ear. Proc. Natl. Acad. Sci. U S A 105, 18776-18781. doi: 10.1073/pnas.0800831105

Otto, C., Fuchs, I., Kauselmann, G., Kern, H., Zevnik, B., Andreasen, P., et al. (2009). GPR30 does not mediate estrogenic responses in reproductive organs in mice. Biol. Reprod. 80, 34-41. doi: 10.1095/biolreprod.108. 071175

Panchin, Y., Kelmanson, I., Matz, M., Lukyanov, K., Usman, N., and Lukyanov, S. (2000). A ubiquitous family of putative gap junction molecules. Curr. Biol. 10, R473-R474. doi: 10.1016/s0960-9822(00)00576-5

Patel, D., Zhang, X., and Veenstra, R. D. (2014). Connexin hemichannel and pannexin channel electrophysiology: how do they differ? FEBS Lett. 588, 1372-1378. doi: 10.1016/j.febslet.2013.12.023

Penuela, S., Gehi, R., and Laird, D. W. (2013). The biochemistry and function of pannexin channels. Biochim. Biophys. Acta 1828, 15-22. doi: 10.1016/j. bbamem.2012.01.017

Penuela, S., Kelly, J. J., Churko, J. M., Barr, K. J., Berger, A. C., and Laird, D. W. (2014). Panx1 regulates cellular properties of keratinocytes and dermal fibroblasts in skin development and wound healing. J. Invest. Dermatol. 134, 2026-2035. doi: 10.1038/jid.2014.86

Pfaffl, M. W. (2001). A new mathematical model for relative quantification in real-time RT-PCR. Nucleic Acids Res. 29:e45. doi: 10.1093/nar/29.9.e45

Pham, C. T., MacIvor, D. M., Hug, B. A., Heusel, J. W., and Ley, T. J. (1996). Longrange disruption of gene expression by a selectable marker cassette. Proc. Natl. Acad. Sci. U S A 93, 13090-13095. doi: 10.1073/pnas.93.23.13090

Piazza, V., Ciubotaru, C. D., Gale, J. E., and Mammano, F. (2007). Purinergic signalling and intercellular $\mathrm{Ca}^{2+}$ wave propagation in the organ of Corti. Cell Calcium 41, 77-86. doi: 10.1016/j.ceca.2006.05.005

Qu, Y., Misaghi, S., Newton, K., Gilmour, L. L., Louie, S., Cupp, J. E., et al. (2011). Pannexin-1 is required for ATP release during apoptosis but not for inflammasome activation. J. Immunol. 186, 6553-6561. doi: 10.4049/jimmunol. 1100478

Qu, Y., Tang, W., Zhou, B., Ahmad, S., Chang, Q., Li, X., et al. (2012). Early developmental expression of connexin26 in the cochlea contributes to its dominate functional role in the cochlear gap junctions. Biochem. Biophys. Res. Commun. 417, 245-250. doi: 10.1016/j.bbrc.2011.11.093

Ray, A., Zoidl, G., Weickert, S., Wahle, P., and Dermietzel, R. (2005). Sitespecific and developmental expression of pannexin 1 in the mouse nervous system. Eur. J. Neurosci. 21, 3277-3290. doi: 10.1111/j.1460-9568.2005. 04139.x

Ren, S. Y., Angrand, P. O., and Rijli, F. M. (2002). Targeted insertion results in a rhombomere 2-specific Hoxa2 knockdown and ectopic activation of Hoxal expression. Dev. Dyn. 225, 305-315. doi: 10.1002/dvdy. 10171

Rodriguez, L., Simeonato, E., Scimemi, P., Anselmi, F., Cali, B., Crispino, G., et al. (2012). Reduced phosphatidylinositol 4,5-bisphosphate synthesis impairs inner ear $\mathrm{Ca}^{2+}$ signaling and high-frequency hearing acquisition. Proc. Natl. Acad. Sci. U S A 109, 14013-14018. doi: 10.1073/pnas.1211869109

Ryder, E., Doe, B., Gleeson, D., Houghton, R., Dalvi, P., Grau, E., et al. (2014). Rapid conversion of EUCOMM/KOMP-CSD alleles in mouse embryos using a cell-permeable Cre recombinase. Transgenic Res. 23, 177-185. doi: 10.1007/s11248-013-9764-x

Scacheri, P. C., Crabtree, J. S., Novotny, E. A., Garrett-Beal, L., Chen, A., Edgemon, K. A., et al. (2001). Bidirectional transcriptional activity of PGK-neomycin and unexpected embryonic lethality in heterozygote chimeric knockout mice. Genesis 30, 259-263. doi: 10.1002/gene.1072

Schütz, M., Scimemi, P., Majumder, P., De Siati, R. D., Crispino, G., Rodriguez, L., et al. (2010). The human deafness-associated connexin 30 T5M mutation causes mild hearing loss and reduces biochemical coupling among cochlear non-sensory cells in knock-in mice. Hum. Mol. Genet. 19, 4759-4773. doi: 10.1093/hmg/ddq402

Scimemi, P., Santarelli, R., Selmo, A., and Mammano, F. (2014). Auditory brainstem responses to clicks and tone bursts in $\mathrm{C} 57 \mathrm{BL} / 6 \mathrm{~J}$ mice. Acta Otorhinolaryngol. Ital. 34, 264-271.

Shpargel, K. B., Sengoku, T., Yokoyama, S., and Magnuson, T. (2012). UTX and UTY demonstrate histone demethylase-independent function in mouse embryonic development. PLoS Genet. 8:e1002964. doi: 10.1371/journal.pgen. 1002964

Skarnes, W. C., Rosen, B., West, A. P., Koutsourakis, M., Bushell, W., Iyer, V., et al. (2011). A conditional knockout resource for the genome-wide study of mouse gene function. Nature 474, 337-342. doi: 10.1038/nature 10163

Sosinsky, G. E., Boassa, D., Dermietzel, R., Duffy, H. S., Laird, D. W., MacVicar, B., et al. (2011). Pannexin channels are not gap junction hemichannels. Channels (Austin) 5, 193-197. doi: 10.4161/chan.5.3.15765

Sun, Y., Tang, W., Chang, Q., Wang, Y., Kong, W., and Lin, X. (2009). Connexin30 null and conditional connexin 26 null mice display distinct pattern and time course of cellular degeneration in the cochlea. J. Comp. Neurol. 516, 569-579. doi: 10.1002/cne.22117

Tang, W., Ahmad, S., Shestopalov, V. I., and Lin, X. (2008). Pannexins are new molecular candidates for assembling gap junctions in the cochlea. Neuroreport 19, 1253-1257. doi: 10.1097/WNR.0b013e32830891f5

Testa, G., Schaft, J., van der Hoeven, F., Glaser, S., Anastassiadis, K., Zhang, Y., et al. (2004). A reliable lac $Z$ expression reporter cassette for multipurpose, knockout-first alleles. Genesis 38, 151-158. doi: 10.1002/gene.20012

Teubner, B., Michel, V., Pesch, J., Lautermann, J., Cohen-Salmon, M., Sohl, G., et al. (2003). Connexin30 (Gjb6)-deficiency causes severe hearing impairment and lack of endocochlear potential. Hum. Mol. Genet. 12, 13-21. doi: $10.1093 / \mathrm{hmg} / 12.1 .13$

Tian, C., Gong, Y., Yang, Y., Shen, W., Wang, K., Liu, J., et al. (2012). Foxg1 has an essential role in postnatal development of the dentate gyrus. J. Neurosci. 32, 2931-2949. doi: 10.1523/JNEUROSCI.5240-11.2012

Tian, Y., James, S., Zuo, J., Fritzsch, B., and Beisel, K. W. (2006). Conditional and inducible gene recombineering in the mouse inner ear. Brain Res. 1091, 243-254. doi: 10.1016/j.brainres.2006.01.040

Tritsch, N. X., Yi, E., Gale, J. E., Glowatzki, E., and Bergles, D. E. (2007). The origin of spontaneous activity in the developing auditory system. Nature 450, 50-55. doi: $10.1038 /$ nature 06233

Wang, H. C., and Bergles, D. E. (2015). Spontaneous activity in the developing auditory system. Cell Tissue Res. 361, 65-75. doi: 10.1007/s00441-0142007-5

Wang, X. H., Streeter, M., Liu, Y. P., and Zhao, H. B. (2009). Identification and characterization of pannexin expression in the mammalian cochlea. J. Comp. Neurol. 512, 336-346. doi: 10.1002/cne.21898

Xu, L., Carrer, A., Zonta, F., Qu, Z., Ma, P., Li, S., et al. (2017). Design and characterization of a human monoclonal antibody that modulates mutant connexin 26 hemichannels implicated in deafness and skin disorders. Front. Mol. Neurosci. 10:298. doi: 10.3389/fnmol.2017.00298

Zhang, H., Chen, Y., and Zhang, C. (2012). Patterns of heterogeneous expression of pannexin 1 and pannexin 2 transcripts in the olfactory epithelium 
and olfactory bulb. J. Mol. Histol. 43, 651-660. doi: 10.1007/s10735-012 -9443-x

Zhao, H. B. (2016). Expression and function of pannexins in the inner ear and hearing. BMC Cell Biol. 17:16. doi: 10.1186/s12860-016-0095-7

Zhao, H. B., Kikuchi, T., Ngezahayo, A., and White, T. W. (2006). Gap junctions and cochlear homeostasis. J. Membr. Biol. 209, 177-186. doi: 10.1007/s00232005-0832-x

Zhao, H. B., Zhu, Y., Liang, C., and Chen, J. (2015). Pannexin 1 deficiency can induce hearing loss. Biochem. Biophys. Res. Commun. 463, 143-147. doi: 10.1016/j.bbrc.2015.05.049

Zheng, Q. Y., Johnson, K. R., and Erway, L. C. (1999). Assessment of hearing in 80 inbred strains of mice by ABR threshold analyses. Hear. Res. 130, 94-107. doi: 10.1016/s0378-5955(99)00003-9

Zhou, X., Jen, P. H., Seburn, K. L., Frankel, W. N., and Zheng, Q. Y. (2006). Auditory brainstem responses in 10 inbred strains of mice. Brain Res. 1091, 16-26. doi: 10.1016/j.brainres.2006.01.107
Zhu, Y., Liang, C., Chen, J., Zong, L., Chen, G. D., and Zhao, H. B. (2013). Active cochlear amplification is dependent on supporting cell gap junctions. Nat. Commun. 4:1786. doi: 10.1038/ncomms2806

Conflict of Interest Statement: The authors declare that the research was conducted in the absence of any commercial or financial relationships that could be construed as a potential conflict of interest.

Copyright (c) 2017 Zorzi, Paciello, Ziraldo, Peres, Mazzarda, Nardin, Pasquini, Chiani, Raspa, Scavizzi, Carrer, Crispino, Ciubotaru, Monyer, Fetoni, Salvatore and Mammano. This is an open-access article distributed under the terms of the Creative Commons Attribution License (CC BY). The use, distribution or reproduction in other forums is permitted, provided the original author(s) or licensor are credited and that the original publication in this journal is cited, in accordance with accepted academic practice. No use, distribution or reproduction is permitted which does not comply with these terms. 